\title{
A THREAT TO ORDER: A VOEGELINIAN EXPLORATION OF MODERNITY, SPIRITUAL CRISIS, AND RESISTANCE
}

\author{
by

\section{Kathleen Lynn Canjar}

A thesis submitted to the Faculty of Graduate and Postdoctoral Affairs in partial fulfillment of the requirements of the degree of

\author{
Masters of Arts \\ in \\ Political Science \\ Carleton University \\ Ottawa, Ontario
}

(C) 2015

Kathleen Lynn Canjar 


\begin{abstract}
The purpose of this thesis is to explore the spiritual crisis that arises because of a disjunct between the symbols that are of the highest concern to an individual society and the overarching Liberal symbols which inform broader narratives. Using Eric Voegelin's theory of representation, this discussion will weigh the consequences of imposing dogmatic "gnostic" approaches against claims that adherence to a single set of symbols is the best way to mitigate conflict and avoid future insecurity. This discussion will analyze the spiritual crisis that arises from pressure to embrace a particular overarching metaphor and the possibility that this spiritual crisis may manifest in the form of a resistance identity, and, furthermore, conflict.
\end{abstract}




\section{Acknowledgments}

I would like to express my sincere gratitude to Professor Darby for his willingness to supervise and take me on as a graduate student. I will be forever thankful for his generosity and guidance throughout this experience. Secondly, I would like to thank Professor Hanvelt for agreeing to be my second reader, and, beyond that, for his support throughout my M.A. Thirdly, I would like to thank Professor von Heykingfirst, for cultivating my interest in political philosophy, and second, for demystifying what is required to learn.

Lastly, but certainly not least, I would like to thank my parents, Vic and Pat, for their endless support and patience while I pursue these "silly" thoughts- I mean education. 


\section{Table of Contents}

Introduction: Modernity, Spiritual Crisis, and Resistance....................................................

Section 1: Eric Voegelin's Theory of Representation .......................................................... 8

I. The Problem of Truth and Representation..........................................................13

A. Elemental and Existential Representation ........................................................14

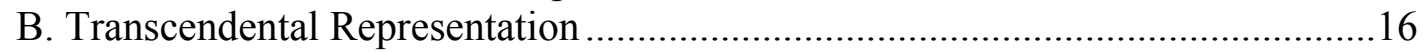

II. Gnostic Formulation \& The Crisis of Modernity ..............................................20

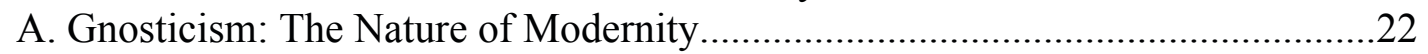

B. The End of Modernity: Consequences of Gnosticism .......................................26

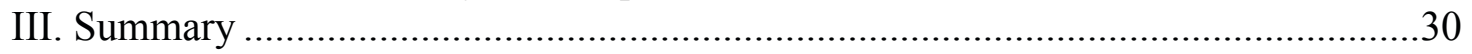

Section 2: Modernity, Globalization and Security ..............................................................34

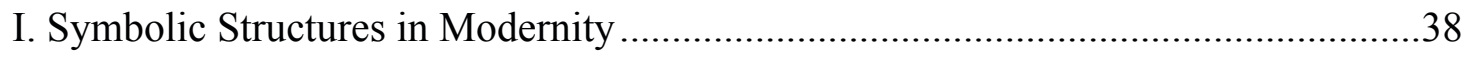

A. Underlying Concerns .........................................................................................

B. The Overarching Metaphor \& Liberalism ...........................................................4

II. Securing Society: The Security of a Universal Overarching Metaphor ...................47

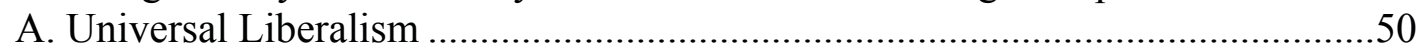

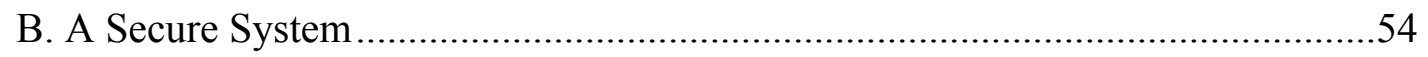

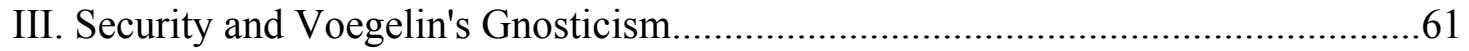

Section 3: Crisis and Resistance ...........................................................................................66

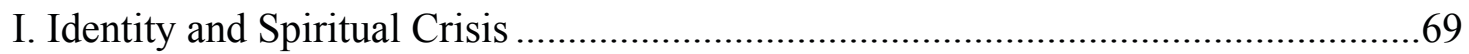

II. Manifestation of Spiritual Crisis: Ontological Security and Resistance ...................77

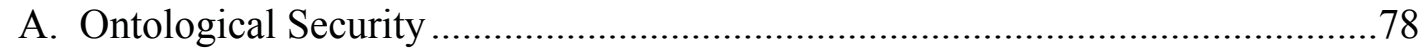

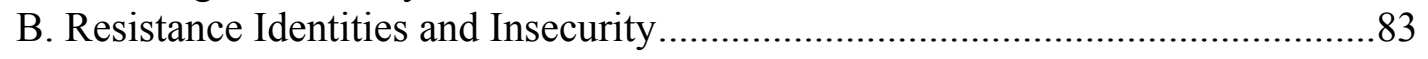

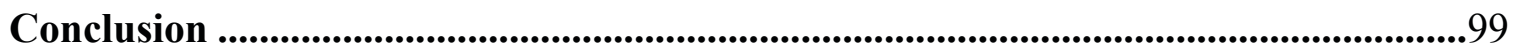

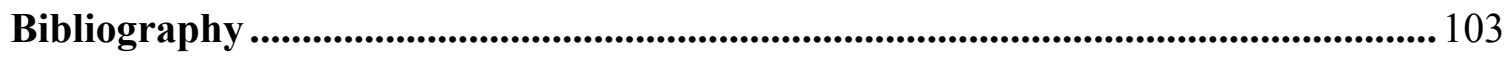




\title{
Introduction: Modernity, Spiritual Crisis, and Resistance
}

\author{
"The death of the spirit is the price of progress." \\ - Voegelin, The New Science of Politics
}

Political discussions, especially those of an international context, are characterized by the question "who has the right to rule the planet?" In international relations, this question is at the centre of the contest for international power, management, and regulation of the processes that order political life. As with any contest, the contest for the planet inevitably has winners and losers: the winners are rewarded with the power to inform broader narratives, and the losers are burdened by a spiritual crisis, as their symbols for making sense of the world become ineffective. The contest for the planet is a "clash of civilizations", to draw on Samuel P. Huntington's popular imagery. ${ }^{1}$ This contest sees contestants confront one another in order to determine who has the best means to organize and rule the planet. ${ }^{2}$ In the current global climate, this contest is characterized by well developed, highly organized, nonWestern civilizations being confronted by the political, economic, and technological power of Western civilization. This spread of values and articulation of a certain truth is a problem born out of the contemporary process of globalization and stimulates a

\footnotetext{
${ }^{1}$ Samuel P. Huntington, “The Clash of Civilizations?”, Foreign Affairs (1993): 22.

${ }^{2}$ Tom Darby, in his article "On Spiritual Crisis, Globalization and Planetary Rule", refers to this contest as an attempt to establish "planetary rule". By this, he means the logical and likely possibility that globalization may lead to the ordering of the planet under the best means to the end of ruling the planet: "none other than the progressive elaboration of the technological world system, which Kojève called the Universal and Homogenous State (U.H.S.)." Darby argues that globalization - the actualization of technology - may be the process that may lead to universal and homogenous rule, a planet ordered by one means, based upon the best technology (Darby, On Spiritual crisis, 58-60).
} 
"crisis of modernity."

This thesis explores the spiritual crisis instilled in the "losers" of this contest for the right to rule the planet. A spiritual crisis arises from a disjunction between the symbols that are of the highest concern to an individual society and the overarching modern — and Liberal — symbols that inform broader narratives. The primary thrust of this thesis is to analyze the conflict between symbols and to question the causes and consequences of resistance identities, identities that rise up to oppose these broader narratives. This discussion aims to provide an account of the philosophical conditions that lead to resistance and conflict by building on Eric Voegelin's description of a spiritual order and the spiritual death present in, and caused by, modernity. To this end, the method for this thesis will be an exegetical analysis of Voegelin's writings and will begin with an explanation of this self-interpretation and articulation of symbols of man's understanding of existence.

It is first necessary to recognize that when a political scientist studies a society, he is not looking at a tabula rasa. Rather, as Voegelin asserts in The New Science of Politics, a political scientist begins with a "rich body of self-interpretation of a society and proceed[s] by critical clarification of socially pre-existent symbols.." ${ }^{4}$ Political

\footnotetext{
${ }^{3}$ Voegelin is one of many theorists who speak of the crisis of modernity. Voegelin's crisis comments upon how modern societies stand in relation to the reality of transcendence, noting that modern society has departed from or severed this relation.

${ }^{4}$ Eric Voegelin, Modernity Without Restraint: The Political Religions; The New Science of Politics; and Science, Politics and Gnosticism, ed. Manfred Henningsen. Vol. 5 of The Collected Works of Eric Voegelin. (Columbia and London: University of Missouri Press, 2000), 110. All citations are from Henningsen's edited version of this text, which includes three of Voegelin's works: The Political Religions, The New Science of Politics: An Introduction, and Science, Politics, and Gnosticism: Two Essays. Most of this thesis draws on the second book, although all three, despite being written under different historical circumstances, are motivated by the desire to pursue questions concerning the modernity and the existential anxiety that accompanied the spread of Western modernity; hence the collective title "Modernity Without Restraint".
} 
science, therefore, does not describe a man or a society's existence for him, but rather reacts to the self-interpretation of existence.

To illustrate Voegelin's point concerning self-interpretation, he asks his reader to consider Aristotle's Ethics and Politics. Voegelin reminds his reader that when Aristotle constructed the concepts that he saw within society, giving them namessuch as the polis, the constitution, and the citizen- Aristotle did not invent these terms. These terms were not pulled from thin air and then endowed with arbitrary meaning, but rather drawn from the symbols Aristotle saw within his social environment. Aristotle took these pre-existing symbols, "surveyed with care the variety of meanings that they had in common parlance, and ordered and clarified these meanings by the criteria of his theory." 5 Thus, Aristotle approached society not as a blank slate over which he could inscribe whatever meaning he wished, but as an entity already filled with meaning. As Aristotle sought to provide clarification to understanding his society, the most important meaning he studied was the meaning society had given itself.

Similarly, consider your own existence. You need not wait for someone to interpret your existence for you, as you have already done so for yourself. You have illuminated meaning from within yourself and, through interaction with the variety of symbolism existing within your social environment, pre-empted the political scientist by creating the mode and condition of your self-realization. If a theorist was to study you and in the process ignored your own understanding of yourself, prescribing his own meaning to your experiences, it would seem wrong - and could potentially even

\footnotetext{
${ }^{5}$ Voegelin, Modernity Without Restraint, 110.
} 
be interpreted as hostile. Your interpretation of your own existence is meaningful: to ignore it would seemingly ignore something integral.

Societies behave in the same way. Each society possesses a narrative that arises from the unique interpretation of its social environment and is representative of the individuals who compose the society. For this reason, a Western society may possess a specific narrative and symbolic structure informed by the self-interpretation of an environment by the individuals living within Western society. Similarly, other societies possess a specific narrative and symbolic structure informed by the individuals of that particular environment. As no society exists in the exact same environment, nor has grown in the exact same historical circumstances, neither society will experience things or come to understand their existence in the same way. Consequently, symbolic structures do not look the same. Every society will arise with a different self-interpretation - a different narrative. These symbolic structures vary, and, sometimes, stand in direct contrast. Furthermore, similar to how it feels wrong if a theorist describes your existence for you, it seems unsettling that some societies interpret and apply meaning to the existence of other societies without considering their individual and unique experiences.

How these symbolic structures are realized is the problem at hand in both Voegelin's The New Science of Politics and in this examination. In The New Science of Politics, Voegelin explores concepts of representation, existence, and truth, examining how societies - and individuals - come to understand existence, how each articulates and produces a representation of itself, and how modernity challenges these 
representations of truth, thus posing a fundamental threat to the order of existence for a given society. This thesis takes Voegelin's analysis a step further, demonstrating how the disjunction between a society's underlying concerns and modernity's “overarching metaphor" ${ }^{\prime 6}$ can result in a spiritual crisis and may culminate in a security threat to international order. Therefore, this thesis draws an important connection between the concept of identity, truth, and security.

Using Eric Voegelin's theory of representation, this discussion will weigh the consequences of imposing dogmatic "gnostic" approaches against claims that adherence to a single set of symbols is the best way to mitigate conflict and avoid future insecurity. In particular, this discussion will analyze the spiritual crisis that can arise from pressure to embrace alternative symbols and the possibility that this crisis may manifest in the form of a resistance identity, culminating in conflict.

To sufficiently address this topic, the organization of this thesis has taken the following schema. The first chapter provides a foundation for a representation of truth fundamental to the larger goals of this examination. It is a detailed exegetical summary of Voegelin's theory of representation and his "crisis of modernity", a crisis created by modern challenges facing society's understanding of existence and political order. Following the exegetical summary, the second chapter provides an understanding of these symbols as representative of either "societal symbols", which represent a society's underlying concerns, or as part of the overarching metaphor, which seeks to globalize one particular set of symbols and unite international society under a

\footnotetext{
${ }^{6}$ This term will be defined later, but in short refers to an expression of shared perceptions and practices shared commonly across a particular age.
} 
homogenous and unified structure for the sake of security. Finally, chapter three describes the consequences that may arise from the disjunction between underlying concerns and overarching metaphors brought to light in chapter two. This chapter offers an explanation of ontological security, formalizing the connection between identity, truth and security. In essence, chapter three carries the argument that there are spiritual and ontological consequences of the overarching metaphor and that the attempt to securitize international society through the universalization of symbols can result in resistance movements that may, paradoxically, lead to greater insecurity.

What this all points to is that there are identifiable philosophical conditions that lead to conflict and insecurity in the international system. Societies must be able to identify their own understanding of existence before international security of any kind can emerge as a possibility.

To conclude, I argue modernity's increasingly technological, scientifically rational, and worldly immanent qualities do not guarantee security. This rrather, as Voegelin posits, may actually be counterproductive, resulting in spiritual crisis and insecurity. Second, I indicate that self-interpretation, including, interpretation of oneself as representative of the beyond, as well as order and continuity regarding ones experiences, is necessary for ontological security. Therefore, only when this element of representation is incorporated into our understanding of order, can security be spoken about realistically. Thirdly, I am concerned with understanding the philosophical conditions that may lead to conflict, not in alleviating them. The only understanding I wish to reach is that the nature of modernity holds within it the 
capacity for potential consequences, which arise due to the loss of the spiritual qualities that modernity represses and eliminates. In saying that, this thesis should not be viewed as a defence of resistance movements - or, in its most radical of manifestations, terrorism - but rather as a critical inquiry into why resistance identities and violent reactions come into existence. It is part of the process of analyzing the significance or importance of a philosophy of security and the importance of self-interpretation, representation, and truth in a world where these fundamental qualities of human nature are systematically ignored. With this in mind, it is with Voegelin's theory of representation and truth that we begin. 


\section{Section 1: Eric Voegelin's Theory of Representation}

"... in its order every society reflects the type of men of whom its composed." - Voegelin, The New Science of Politics

Eric Voegelin's The New Science of Politics originally took the form of six Walgreen lectures given at the University of Chicago in 1951. The lectures were given under the title of the specific problem it tackled, "Truth and Representation", with the subtitle of "The New Science of Politics". In 1952, these lectures, along with borrowed material from Voegelin's larger project on representation, were published under its current name: The New Science of Politics. The title was designed to signify the drastic shift Voegelin's approach took from the traditional study of political science. ${ }^{7}$ Voegelin articulated this difference in 1971 at a conference held at Notre Dame University to celebrate the $20^{\text {th }}$ anniversary of these lectures:

What was new about this was the conception that political science is not a straight statement of propositions concerning a reality which is somewhere lying around as a datum and can be simply stated as true [....] furthermore, on that occasion, a factor of newness was the consciousness that we do not deal with actions or rather [behaviour] in the external world and in politics, but with states of consciousness, with states of experiences, so that the central problem in every analysis of social order would be the analysis of the experiences which produce the symbols in which a society expresses its order. That analysis of symbols is certainly a central problem for Plato and Aristotle, but is almost eliminated from contemporary political science. So, the

\footnotetext{
${ }^{7}$ The purpose of The New Science of Politics was to analyze the crisis facing civilization in the 20th century, particularly regarding the rise of radical ideologies and the carnage that arose with them. Michael Franz presented Voegelin's response to the crisis of modernity as threefold: 1) uncover the historical and experiential basis of the problem; 2) develop tools for understanding the problem; and $3)$ prescribe a way to foster recovery. For further information see: Michael Franz, Eric Voegelin and the Politics of Spiritual Revolt: The Roots of Modern Ideology. Baton Rouge: Louisiana State University Press, 1992.
} 
complete presentation of the experiences as the origin of symbols, and then the changes of these experiences that are called "representation" with other changes in history, and therewith the changes in the symbols, are an important part of political science, and that was the new element I tried to introduce. ${ }^{8}$

For Voegelin, analysis of experience is key to understanding how a society articulates itself and how society expresses its order. This difference in contemporary political methodology allowed Voegelin to move away from the concept of "an idea" to the concept of "a symbol", and to speak of a philosophy of politics, or of order and history. Furthermore, it aimed to develop a philosophy to characterize the differentiated "consciousness of existence as the centre of all truth and symbolization concerning the existence of man," it creates.

The New Science of Politics begins with an explanation of Voegelin's project. He asserts: "the existence of man in political science is historical experience; and a theory of politics, if it penetrates to principles, must be at the same time a theory of history." ${ }^{10}$ By this, Voegelin means that if one intends to understand how society is ordered and the meaning of existence, it is vital to look at the history of man and the principles that have evolved from his history. Only then can a theorist understand

\footnotetext{
${ }^{8}$ This quote from Voegelin was recorded by Stephen A. McKnight in McKnight's remarks on the 1971 Notre Dame University conference held to pay tribute to Voegelin's contribution to the restoration of political science. McKnight's article includes numerous quotes by Voegelin, detailing his views on his work. This quotation is one of Voegelin's opening remarks on his work, establishing his purposes writing The New Science of Politics. Voegelin also remarked that while his efforts articulated some of the problems of representation, it remains the core issue in the Western experience of order. For further interest, please see: Stephen A. McKnight, "Gnosticism and Modernity: Voegelin's Reconsiderations Twenty Years After The New Science of Politics," Political Science Reviewer Vol. 34 (2005): 122.

${ }^{9}$ McKnight, 122.

${ }^{10}$ Voegelin, Modernity Without Restraint, 88.
} 
society. Therefore, Voegelin's task is to examine the fundamental problem of politics, a task that requires the investigation be carried beyond a "description of the conventionally called representative institutions into the nature of representation as the form by which a political society gains existence for action in history." ${ }^{, 1}$ Voegelin aims to examine the manifold of symbols that make up the truth of society; the truth of society being not just the body of propositions derived from a world-immanent object, but also from world-transcendent experience as an orientating force in the soul and for the identity of individuals and society.

In order for Voegelin to examine the truth of society, or the truth of existence, it was necessary for him to dispel what Voegelin views as the myth of positivism. It was Voegelin's first task to explain how positivism fails to account for much of human existence. This required Voegelin to examine the issues of a value-free political science, as championed by Max Weber. This value-free political science concentrates on world-immanent truth and ignores world-transcendent experiences, focusing solely on the data that the theorist could state as simply true.

Positivism has two assumptions: 1) all sciences must emulate the mathematizing natural sciences; and 2) whether or not the methods of the natural sciences are used determines theoretical relevance. ${ }^{12}$ The second assumption is the source of real danger. It led to the following assertions: a study of reality is only scientific if it follows the scientific method; problems expressed in other terms are false, or illusions; and realms of being inexplicable by the chosen methods, such as

\footnotetext{
${ }^{11}$ Voegelin, Modernity Without Restraint, 88.

${ }^{12}$ Voegelin, Modernity Without Restraint, 90-91.
} 
metaphysical questions, are irrelevant or non-existent. Voegelin asserts that establishing methodology as the fundamental criterion of political science perverted the discipline, as there cannot be laws of social phenomenon in the same way that there are laws of natural sciences. ${ }^{13}$ As science is the search for truth in various realms of being, scientific investigation must vary in means. Overall, positivism contributes to the accumulation of irrelevant facts and misinterpretation of relevant facts. While some useful analysis does occur with positivism, positivism also abolishes theoretical relevance as facts are promoted to the status of science regardless of their level of importance to the existence of man and his participation in reality.

Positivism was founded on the idea that propositions concerning facts about the phenomenal world were "objective", while judgements concerning a worldtranscendent experience are "subjective" and therefore scientifically invalid. Voegelin aims to restore political science by rediscovering the rationality of metaphysics and philosophical anthropology. It is Voegelin's purpose to change how political science is used. He intends to relieve political science from the

contraction of political science to a description of existing institutions and the apology of their principles, that is, the degradation of political science to a handmaiden of the powers that be, has been typical for stable situations, while its expansion to its full grandeur as the science of human existence in society and history, as well as the principles of order in general. ${ }^{14}$

This is not a simple task. The New Science of Politics is profoundly important to

\footnotetext{
${ }^{13}$ Voegelin, Modernity Without Restraint, 89.

${ }^{14}$ Voegelin, Modernity Without Restraint, 89.
} 
elevating political science to include the experiences, values, and symbols instrumental to unearthing a society's truth.

In this series of lectures, Voegelin seeks to examine societies by exploring the symbols that societies use to understand themselves. Broadly, the lectures can be split into two parts. The first three lectures, which became the first half of Voegelin's book, deal with the problem of truth and representation in the classical and Christian sense. These lectures discuss how societies become ordered for action, specifically analyzing political representation in the existential and transcendent sense. The second three lectures dealt with the Gnostic formulation, which Voegelin saw as the crucial problem of modernity and as the impending "crisis". Here, Voegelin introduces us to the concept of "gnosticism", a type of thinking which claims mastery of reality and views itself as not subject to criticism. Gnosticism is a modern aberration that in Voegelin's view, is responsible for the "death of the spirit" 15 and the movement away from political order. These final three lectures, which became the second half of The New Science of Politics, argue that modernity will continuously cause disorder and war, as it only deals with a de-divinized man, repressing the truth of the soul and the principles of existence, and consequently marginalizes fundamental qualities of human nature.

These lectures begin Voegelin's inquiry into how symbols are used by societies to articulate truth, how society's interpret their existence and understand their place in the world. He also examines the dangers of modernity, dangers that seemingly strip society of its transcendent representation and therefore its truth. Voegelin's lectures

\footnotetext{
${ }^{15}$ Voegelin, Modernity Without Restraint, 195.
} 
lend specific insight into this "clash of civilizations." It is this "clash" of competing articulations of truth that is analyzed in the following chapters of this thesis, beginning with an outline of the main thought of Voegelin's project.

\section{The Problem of Truth and Representation}

As summarized above, The New Science of Politics can be broadly split into two parts. This examination will begin by describing the first lectures of Voegelin's book. These chapters deal with the problem of truth and representation. Here, Voegelin offers an explanation concerning how societies become ordered for action by examining the symbolic structures through which societies articulate their truth. Voegelin's first lecture, titled "Representation and Existence", discusses political representation in the elemental and existential sense. The second lecture, called "Representation and Truth", examines a third layer of representation key to examining this problem, which is the discovery of transcendental truth. Voegelin's third lecture, titled "The Struggle of Representation in the Roman Empire", discusses the new salvational truth of Christianity.

Voegelin begins these lectures by stating that human society is "not merely a fact, or an event, in the external world" and while "externality [is] one of its important components", human society is also "illuminated with meaning from within by the human beings who continuously create and bear it as the mode and condition of their self-realization." ${ }^{16}$ As explained in the introduction, political science does not interpret human existence for society, rather society self-illuminates on several levels and

\footnotetext{
${ }^{16}$ Voegelin, Modernity Without Restraint, 109.
} 
articulates understanding of societies' truth through symbols.

Articulation is a condition of representation. Political society comes into existence when it is able to articulate and produce a representation of itself. This representation is created through the materialization of a symbolic structure. Voegelin calls this interpretation of a political society a cosmion, which has an inner realm of meaning but which also exists tangibly in the external world. ${ }^{17}$ Voegelin writes of three types of representation, or three ways that symbolism materializes: elemental, existential, and transcendental. It is only by understanding all three types of representation that the symbolic structure articulated by societies can be understood, and how the problem of representation can be exhausted.

\section{A. Elemental and Existential Representation}

The most common form of representation is elemental representation, which refers to the external existence of society. Voegelin states that this is an appropriate place to begin, as symbolism is experienced "tangibly in the external world in human beings who have bodies and through their bodies participate in the organic and inorganic externality of the world." ${ }^{18}$ Most commonly, we speak of representative institutions as indicative of the external existence of society, or political society in action.

Elemental representation includes various agencies that act as a binding force within society, including, the laws and institutions, as well as specifics such as the

\footnotetext{
${ }^{17}$ Voegelin, Modernity Without Restraint, 120.

${ }^{18}$ Voegelin, Modernity Without Restraint, 112.
} 
mechanics of voting, and geographical districts. These representations can manifest in many forms, from representation by royal hierarchies, to democratic parliaments, to totalitarian regimes. In Western society, elemental representation is commonly seen in the expression of "government of the people", where the people are both the representative and the membership. In short, elemental representation is the external existence of a society; it is tangible and contains easily identifiable characteristics key to understanding a society. But elemental representation is an insufficient understanding of the existence of society and political science should not stop its investigation at this level.

Voegelin tackles the idea of existential representation, which works in conjunction with external representation. Existential representation signifies the idea, spirit, or political culture that animates a society - the actualization of the spirit or idea of a society. To illustrate the difference between elemental and existential representation, Voegelin cites the representative character of the institutions of the former Soviet Union. He explains that the formal institutions represent the elemental type, but the constitution, which provides for these institutions, is existential representation. The constitution represents the idea, spirit and political culture of the Russian people and is the doctrine from which the elemental institutions arise. Furthermore, Voegelin stresses that the elemental representation discussed above must match the existential reality of society; otherwise the institutional representations of society will become irrelevant. Regardless, in the case of the former Soviet Union, Voegelin stresses that a theorist will learn very little about the reality of Russian 
society from reading its constitution, because constitution, though beautifully written, does not conform to the existential reality of the one-party totalitarian regime. ${ }^{19}$

Consequently, the external and existential representations - political symbols that exist in reality — are not enough to account for some of the fundamental questions of existence. These representations are realizations of only one special type of articulation and representation. Additionally, elemental concepts of representations are insufficient, as there can be varying views on what systems are representative of truth, and there may be situations where existential representations do not reflect their external reality. In order to answer these fundamental questions of existence, representation in the transcendental sense must be considered. The crisis of Western civilization, discussed in the latter three chapters, is the failure to accept the importance of these inner-expressions of truth.

\section{B. Transcendental Representation}

Voegelin reminds us that society is illuminated from within and subject to its own self-interpretation, and in order to fully exhaust representation, it is vital to look at the representations of truth found in a political societies' history, the way a society is representative of something beyond itself, and not just its articulated representatives. This is Voegelin's third level of representation, which exists beyond existential and elemental representation, namely, transcendent representation. Transcendent representation reflects attempts by a society to interpret itself as a representative of

\footnotetext{
${ }^{19}$ Voegelin, Modernity Without Restraint, 114-116.
} 
something beyond, or transcendent to, itself. $^{20}$

Transcendence truth emerges as a way for political societies to understand themselves. In the earliest of Voegelin's examples, empires understood themselves as representative of a transcendent order, or as representative of the order of the cosmos, and some have interpreted this as truth. This establishment of truth as indicative of something beyond the world-immanent provides a political society with meaning and reason to act in a particular way. A political society, as a result, acts as a "cosmic analogue, [or] a little world reflecting the order of the great, comprehensive world."21 Simply put, transcendent representation provides a political society with an account of is meaningfulness, justice, place, and mission in the cosmic order. It allows societies to order themselves in line with a specific purpose, a purpose that unifies a society's people.

To illustrate the importance of this layer of representation, Voegelin points to several examples throughout history. He states that all early empires, from the ancient Near East to the Far East, were ordered by symbols that acted a representative of a cosmic order. The influence of the "self-understanding of a society as a representative of a cosmic order originates in the period of the cosmological empires in the technical sense, but it is not confined to this period, ${ }^{, 22}$ but rather can be seen in the imperial symbols of the Western Middle Ages and extends into modernity. Voegelin cites the example of Marxist dialectics, where the truth of the cosmic order has been replaced

\footnotetext{
${ }^{20}$ Voegelin, Modernity Without Restraint, 130.

${ }^{21}$ Voegelin, Modernity Without Restraint, 131.

${ }^{22}$ Voegelin, Modernity Without Restraint, 134.
} 
by the truth of a historically immanent order. ${ }^{23}$ The truth may be symbolized in an entirely different manner, but its purpose, the illumination of self-understanding, remains the same:

[its] order is harmony with the truth of truth of history; its aim is the establishment of the realm of freedom and peace; the opponents run counter to the truth of history and will be defeated in the end; nobody can be at war with the Soviet Union legitimately but must be a representative of untruth in history, or, in contemporary language, an aggressor; and the victims are not conquered but liberated from their oppressors and therewith from the untruth of their existence. ${ }^{24}$

As this quote indicates, the meaning of truth becomes clearest when a society is under attack. Prior to conflict, it appears as if all political societies could be entities expressing a universal truth. Yet, in situations when societies come into conflict, those on the side of a society's understanding of order represent truth, and their enemies represent disorder and falsehood. These meetings of transcendent truth versus transcendent truth test the validity of what constitutes order and, as Voegelin states, sets up a "historical event of major dimensions.",25

Furthermore, Voegelin sees society as indicative of man, echoing Plato's well known sentiment of "the polis is the man written large." 26 By this Voegelin means that, while political society is an ordered cosmion in itself, it does not exist at the expense of man. Rather, in its order "every society reflects the type of men of whom it is composed." 27 As an example, a cosmological order would be made up of men who

\footnotetext{
${ }^{23}$ Voegelin, Modernity Without Restraint, 134.

${ }^{24}$ Voegelin, Modernity Without Restraint, 134.

${ }^{25}$ Voegelin, Modernity Without Restraint, 135.

${ }^{26}$ Plato, Republic, 368c-d, as quoted in Voegelin, Modernity Without Restraint, 136.

${ }^{27}$ Voegelin, Modernity Without Restraint, 136.
} 
experience the truth of their experience in harmony with the cosmos. Consequently, political order, defined through the three forms of representation, also expresses a specific human type and says something about the humans that make up a society. Political order is founded on the level of experiences.

Together, these three types of representation supply a comprehensive understanding of how a society self-illuminates its own truth and political order. These types of representation articulate the specific narrative and symbolic structure of a political society, informed by its environment and its understanding of the transcendent, experiences which order a society in a particular way. Together, these types of representation indicate a society's societal symbols, which are indicative of a society's underlying concerns, the things that are of the highest importance to a society. These underlying concerns will be examined in more depth in the next chapter, but are broadly defined as the concerns are the symbols which give meaning to an individual's and society's existence, allowing people to focus on that which concerns them the most.

To summarize, political societies will develop unique symbolic structures: each society will arise with a different self-interpretation and a difference narrative, unique to its own experiences and representative of the experiences of the men who make up its society. The symbolic structures will vary between societies, and perhaps even stand in direct contrast. These unique experiences will stimulate disagreement. Disagreement will shock convictions and will heighten tension. This tension will sees contestants confront one another in order to determine who has the best means to 
organize and rule the planet. Voegelin's theory of representation clearly established, it is to the conflict in modernity that we turn.

\section{Gnostic Formulation \& The Crisis of Modernity}

The second part of Voegelin's The New Science of Politics, the final three lectures, deals with the problem of representation found in modernity. In modernity, the symbolic structures of political societies have been disrupted. Recall that a symbolic structure is formulated by the experiences of men and articulated by three levels of representation. These three levels of representation need to exist harmoniously in order for society to progress, succeed, and act as a source of order. If one or more of levels are disrupted, the underlying concerns of society become irrelevant and society can fall into a state of spiritual crisis. Modernity, through the growing influence and use of technology, has allowed for different symbolic structures to come against each other, each vying to be the structure which can best order the planetary system. This battle for the best symbolic structure falls into the realm of what Voegelin calls "gnosticism", which is the topic explored in Voegelin's latter three lectures. ${ }^{28}$ Voegelin argues that gnostic doctrines are imposed upon societies, imploring people to turn away from transcendence and towards civilization activity, and in the process rendering a society's representations of truth irrelevant. This, for Voegelin, is the nature of modernity.

\footnotetext{
${ }^{28}$ Gnosticism is Voegelin's term for the modern ideological tendency to claim secret and certain knowledge of reality. Although parallel, it should not be confused with the original Gnostic movement. Voegelin himself moved away from the term "gnosticism" (though he retained his original shorthand "gnosis", an element of gnosticism) in order to avoid confusion between the technology concept he wished to portray and the ancient historical movement.
} 
Gnostic doctrines contribute to the de-divinization of society. These doctrines disrupt or eliminate the role that transcendent representation plays within political society. Voegelin refers to this turn away from transcendence towards more temporal ways of living as the "crisis of modernity". While Voegelin admits that modernity has benefits, he asserts that "civilization can, indeed, advance and decline at the same time." ${ }^{29}$ Modernity challenges civilization in a way that causes civilization to lose its spiritual foundation, as civilization is challenged by ideological persuasions:

The death of the spirit is the price of progress. Nietzsche revealed this mystery of the Western apocalypse when he announced that God was dead and He had been murdered. This gnostic murder is constantly committed by men who sacrifice God to civilization. The more fervently all human energies are thrown into the great enterprise of salvation through worldimmanent action, the farther the human beings who engage in this enterprise move away from the life of the spirit. And since the life of the spirit is the source of order in man and society, the very success of the gnostic civilization is the cause of its decline. ${ }^{30}$

In Voegelin's view, and in the view of this thesis, modernity is the prime cause of this spiritual crisis, because modernity consists of certain qualities that contribute to the stripping of a societies' spirituality or transcendent representation. Such symbols are integral to a society's articulation of truth and which make up a society's underlying concerns. Key to Voegelin's position is the idea that the spirit is a source of order in man and society. Without the presence of this spirituality, society begins to corrode. Consequently, Voegelin asserts at the beginning of Lecture IV that the modern problems of representation could be corrected by a re-divinization of man and society by allowing a reinstatement of the transcendent qualities that inform the existence of

${ }^{29}$ Voegelin, Modernity Without Restraint, 195.

${ }^{30}$ Voegelin, Modernity Without Restraint, 195. 
man and society. ${ }^{31}$ If society is not re-divinized, modernity will cause a civilization to decline, and when this delicate balance between advancing and declining falters, the "limit is reached [and] an activist sect that represents the gnostic truth organized civilization into an empire under its rule. Totalitarianism, defined as the existential truth of gnostic activists, is the end form of progressive civilization."32

These lectures primarily deal with Voegelin's articulation of the gnostic formulation, a problem of representation and the specific element of modernity that contributes to the death of the spirit and the corrosion of society. The following will summarize Voegelin's conception of the key nature of modernity: the problem of gnosticism.

\section{A. Gnosticism: The Nature of Modernity}

Voegelin is concerned with the nature of modernity and this nature is gnosticism. Voegelin writes that modernity can be defined as "the growth of gnosticism" and, consequently, modernity is a time that is in crisis. Specifically, the growth of gnosticism is indicative of de-divinization, a "historical process in which the culture of polytheism died from a experiential atrophy, and human existence in society became reordered through the experience of man's destination."33 Modernity is therefore full of societies who have ordered themselves not in line with the truth of the soul, derived from the self-illumination of societies based on their transcendental truth, but through more worldly means.

\footnotetext{
${ }^{31}$ Voegelin, Modernity Without Restraint, 175.

${ }^{32}$ Voegelin, Modernity Without Restraint, 195.

${ }^{33}$ Voegelin, Modernity Without Restraint, 175.
} 
As gnosticism is seen to be the essence of modernity, Voegelin devotes these lectures to the analysis of this topic and the negative impact gnosticism has had on political society. Gnosticism, derived from the Greek word gnôsis, meaning "knowledge" or "insight", is a type of thinking which claims mastery of reality and views itself as not subject to criticism. Gnostic movements embody a specific vision of truth, which is undertaken and seen as authoritative without critical reflection. This vision of truth arises from specific knowledge of how to change the order of being and history to correct an unsatisfactory world that is "intrinsically poorly organized". 34

Voegelin further defined gnosticism as "a purported direct, immediate apprehension or vision of truth without the need for critical reflection; the special gift of a spiritual and cognitive elite. ${ }^{, 35} \mathrm{He}$ saw gnosticism as having the potential to take one of two forms. First, in the case of the gnostic movements of late antiquity, gnosticism took the form of transcendentalization. Second, gnosticism can take an immanentizing form. Voegelin believes gnosticism takes the second form in modernity as modern gnosticic focus on the reorientation of societies towards the worldimmanent. Voegelin sees modernity’s gnosticism as "receding from transcendence"36 and attempting to transform political society into a world-immanent civilization, thus

\footnotetext{
${ }^{34}$ In Science, Politics, and Gnosticism: Two Essays, Voegelin lists the six features of gnosticism which, stated concisely, are: 1) dissatisfaction with one's situation; 2) belief that the reason the situation is unsatisfactory is that the world is "intrinsically poorly organized"; 3 ) that salvation from the evil of the world is possible; 4) the order of being will have to be changed through a historical process; 5) to rid a situation of evil, human action must change the order of being; and 6) and changing the order of being in history is possible if one knows how. Gnosis is the knowledge concerning how (297298).

${ }^{35}$ While Voegelin's The New Science of Politics offers an in-depth description of his opposition to what he believed to be unsound Gnostic influences in politics, Voegelin's most succinct definition of Gnosticism is found in Voegelin's Autobiographical Reflections. See the Voegelin Glossary: Eric Voegelin, Autobiographical Reflections, ed. Ellis Sandoz, Vol. 34 of The Collected Works of Eric Voegelin, (Columbia: University of Missouri Press, 2006), 160.

${ }^{36}$ Voegelin, Modernity Without Restraint, 193.
} 
building society without the spiritual and eliminating key elements of man's experience. Therefore, when speaking in the context of modernity, Voegelin uses the term negatively, seeing the gnostic influence in politics as unsound. Modern gnosticism severs political society, because it removes necessary qualities of representation and fails to completely illuminate the self-realization of society.

Modern gnosticism, therefore, has two major intended effects. First, it creates disorder in the world, which Voegelin calls "gnostic speculation". Gnostic speculation theorizes that disorder in the world will be overcome by knowledge. As this knowledge does not need criticism, the belief is that it will easily transcend the world, creating order by universal acceptance. Second, modern gnosticism aims to create a sort of human on earth within history, bringing the Christian eschaton into the immanent world. This, as mentioned before, completely severs the transcendent from political society in terms of order creation.

It is these two effects that are the intended goal of modernity's gnostic revolution, the subject of Voegelin's fifth lecture. Voegelin writes, "modern gnosticism rises victoriously to predominance over a civilizational tradition deriving from truth." ${ }^{, 37}$ Here, Voegelin introduces his gnosticism thesis which criticizes modernity by identifying an "immanentist eschatology"38 within its essence. By this, Voegelin means that modernity moved away from transcendent representation by attempting to bring the eschaton, or the final heaven-like stage, into the immanent world. Its goal is that society will reject the Christian eschaton of the Kingdom of God,

\footnotetext{
${ }^{37}$ Voegelin, Modernity Without Restraint, 196.

${ }^{38}$ Voegelin, Modernity Without Restraint, 234; 240-41.
} 
and man's self-illuminated truth as representative of something beyond themselves, and replaces transcendental truth with a human form of salvation, this salvation being found in what is scientific and rational, namely, technology.

The goal of gnosticism is to build a society independent of the spirit. Gnosticism champions a way of organizing and ruling the planet according to a temporal truth, seeing representation of a relation to something beyond as unnecessary for order in the world-immanent. Thus, gnosticism eliminates human experience, as it ignores the transcendent representation that Voegelin sees as key to establishing an ordered and representative society, and creates a material civilization. The primary characteristic of this society is the advancement of a cause through existential methods, and organizing behind a select group of humanity who are percieved as elite. These elite are seen as the only party privy to "truth," and thus the only party with the means to establish the perfect society. ${ }^{39}$

This gnostic revolution is new to society and the order it champions juxtaposes the spiritual and wholesome order that Voegelin outlined in his first three lectures. While the representative order Voegelin describes embraces all areas of human experience (elemental, existential, and transcendent), a gnostic order descends to the level of existential representation. While connected to the representation of truth, the gnostic revolution ignores specific elements of history and experience. Gnosticism has the tendency "not to supplement but to supplant the truth of the soul."

\footnotetext{
${ }^{39}$ Voegelin, Modernity Without Restraint, 199.

${ }^{40}$ Voegelin, Modernity Without Restraint, 221.
} 


\section{B. The End of Modernity: Consequences of Gnosticism}

In his final lecture, "The End of Modernity", Voegelin discusses the consequences that are derived from modernity's gnostic nature. Primarily, Voegelin cites two main dangers of gnosticism. First is the destruction of the truth of the soulof transcendental representation - as "wherever gnostic movements spread they destroyed the truth of the soul. ${ }^{.41}$ As discussed before, gnostic societies are concerned with the existential representation of the world-immanent. These societies repress the soul altogether and therefore eliminate a segment of experience and self-illumination that is key to a man's existence.

Second is gnosticism's production of principles that run counter to the principles of existence. Existence, for many societies, and in Voegelin's view for all societies, is determined by something spiritual. The "eschatological interpretation of history results in a false picture of reality ${ }^{\prime 42}$ because it destroys the seminal wisdom of societies in that their purpose is grounded in something higher:

A society, when it exists, will interpret its order as part of the transcendent order of being. This self-interpretation of society as a mirror of cosmic order, however, is part of social reality itself. The ordered society, together with its understanding, remains a wave in the stream of being; the Aeschylean polis with its ordering Dike is an island in a sea of demonic disorder, precariously maintaining itself in existence. ${ }^{43}$

Thus, the gnostic formulation destroys a societies' reason for existence. It undercuts man's understanding of his purpose and produces principles that run counter to the

\footnotetext{
${ }^{41}$ Voegelin, Modernity Without Restraint, 221.

${ }^{42}$ Voegelin, Modernity Without Restraint, 223.

${ }^{43}$ Voegelin, Modernity Without Restraint, 224.
} 
articulation of society.

Gnostocism, then, is dangerous as it is self-defeating on account of its inherent principles. This is seen in two major consequences: alienation and repression. These consequences will be described here in the context of Voegelin's argument, but further elaborated upon in the following chapters.

Despite the gnostic influence on politics being unsound, the consolidated gnostic experience resonates with the individuals who compose a society. The truth of the gnostic revolution breeds "separation between such and the rest of the world, so that, as a consequence, mankind will be divided into the "brethren" and the "worldings." "44 Gnosticism takes hold of a society, gains wide acceptance, and rises to a point where it is "difficult, if not impossible, to break [the gnostic truth] up by persuasion." ${ }^{, 45}$ Gnostic societies become champions of the one and only truth and become impervious to argument, moving towards the idea of a universal international society.

Furthermore, the function of gnosticism becomes to place itself as the civil theology of all societies. Gnosticism begins to try to construct "order out of isolated individuals [or societies] who are not orientated toward a common purpose but only motivated by their individual passions. ${ }^{, 46}$ This takes societies who understanding of truth alienates them from others and attempts to organize them under the same values. This mission creates an "us versus them" attitude, where societies prefer the company of the like-minded, rather than the strangers from the rest of the world, whose values

\footnotetext{
${ }^{44}$ Voegelin, Modernity Without Restraint, 199.

${ }^{45}$ Voegelin, Modernity Without Restraint, 199.

${ }^{46}$ Voegelin, Modernity Without Restraint, 235.
} 
arise from unfamiliar experiences. The rest of the world is seen as being proponents of an untrue doctrine. This alienates societies because their understanding of existence is now interpreted for them: an individual's self-illumination is deemed wrong and unnecessarily tied to something otherworldly. As other societies champion what is seen to be a "lie", their own understanding of truth is targeted for elimination and their existence becomes prescribed for them.

This leads into the second consequence of the gnostic revolution: repression. Societies are alienated in their experiences as the gnostic movement aims to spread and wherever they spread they destroy the truth of the soul:

The material civilization of the West, to be sure, is still advancing; but on this rising plane of civilization is the symbolism of contributions, commemoration, and oblivion draws the contours of those "holes of oblivion" into which the divine redeemers of the gnostic empires drop their victims with a bullet in the neck. ${ }^{47}$

Westernization is one of the most profound consequences of the gnostic revolution. Voegelin argues that immanentist eschatology is found predominantly in the West, where the removal of the spiritual from political organization has been seen as a principle that will order not only individual societies, but will order the world as a whole under one version of truth. The gnostic revolution, and thus adherence to a single set of symbols, is seen as the best way to mitigate conflict and avoid future insecurity.

Yet, Voegelin argues the opposite. He writes: "gnostic politics is self-defeating in the sense that measures that are intended to establish peace increase the disturbances

${ }^{47}$ Voegelin, Modernity Without Restraint, 194. 
that will lead to war." ${ }^{, 8}$ This is because modernity can "repress the truth of the soul ... but it can not remove the soul and its transcendence from the structure of reality"49 and consequently modernity's tendency to recede from transcendence causes disorder. Therefore, while modern gnosticism will aim to repress the transcendent from being in the order of society, transcendence will not go away easily.

Rather, Voegelin questions how long this repression can possibly last. Voegelin argues that prolonged and severe repression of the soul will inevitably lead to a backlash. This is because, while Westernization has seemingly embraced a political order without transcendence, the same cannot be said for other societies, such as Chinese, Hindu, Islamic and primitive civilizations, whose interpretation of existence is still reliant on transcendent experience. Consequently, faced with prolonged exposure to the devastation of the gnostic revolution, these societies will, at some point, rise up to defend their personal interpretations of existence. Inevitably an explosion of resistance will take place, as the transcendent experience of man cannot be silenced easily.

It is for this reason that Voegelin argues that the planet is experiencing a "crisis of modernity". Gnosticism, in that it forces societies to abandon the symbols they have articulated for themselves, as the previous section of this chapter described, poses a critical philosophical issue, one that is described in the chapters to come.

\footnotetext{
${ }^{48}$ Voegelin, Modernity Without Restraint, 227.

${ }^{49}$ Voegelin, Modernity Without Restraint, 222.
} 


\section{Summary}

The exegetical analysis done in this chapter speaks to the comments issued in the introduction: societies self-interpret and articulate the meaning of existence for themselves. The action of self-interpretation is fundamental to a society's development of its identity and only through this articulation of symbolic structure can one identify a society's underlying concerns, a concept that will be vital to the remaining chapters of this thesis as it turns to an analysis of security.

What The New Science of Politics successfully demonstrates is that there is a critical challenge facing a societies articulation of truth and representation within modernity. While Voegelin's understanding and analysis of gnosticism has been criticized, primarily for being too widely applied, the merit of his analysis is that Voegelin's theory points to some major philosophical challenges facing a society in modernity, particularly in that a society's underlying concerns can be uprooted due to modernity's focus on the world-immanent. ${ }^{50}$ Gnosticism, as it seeks to impose a

\footnotetext{
${ }^{50}$ Voegelin used the language of "gnosticism" to illuminate issues surrounding important issues regarding the fundamental order of human existence and the ways it can fall into crisis. Yet, Voegelin's denunciations of gnosticism have been criticized and some who read his analysis remain skeptical of the value of his examination. For example, Thomas J. J. Altizer once said: "Professor Voegelin finds everything to be Gnostic." McKnight and Franz, in other examinations, have shown that the categories of thought and symbolism which Voegelin lumps under "gnosticism" is perhaps too inclusive, and have suggested other terms to replace it, such as Franz's "pneumopathological consciousness." McKnight and Franz have also suggested that the exploration of gnosis has rapidly advanced, which has caused issues with tracing a direct line of descent of gnostic historical sources to the modern phenomena Voegelin tried to illuminate (See: Stephen A. McKnight, The Modern Age and the Recovery of Ancient Wisdom: A Reconsideration of Historical Consciousness, 14501650. Columbia: University of Missouri Press, 1991; and Franz's Eric Voegelin and the Politics of Spiritual Revolt). Furthermore, Voegelin's own use of the term, although rich and meaningful, covers many distinct problems, making its "richness" part of the problem and contributing to its generality and impreciseness. Voegelin himself recognized this when, in 1978, he said that besides what was usually referred to as "gnostic", Voegelin's work addressed strands not encompassed in
} 
specific symbolic order, dismantles the symbolic orders self-interpreted by the societies. This poses, as Voegelin posits, a problem concerning interpretations of the existence of man. The basic tenets of gnosticism are observable in modernity as new symbolic structures, leading to a new overarching metaphor, as examined in the next chapter.

Voegelin's discussion of gnosticism is integral to demonstrating how a move towards a more scientific and rational symbolic structure - similar to the positivist notions which Voegelin challenged in the beginning of The New Science of Politicscan prove disorientating to societies who have articulated their own interpretation and who have their own symbolic structures. Gnosticism stirs up sentiments of alienation and repression - sentiments that will play a role in generating insecurity, as examined in chapter three.

To summarize, the given analysis is critical to the following chapters for two reason. First, the beginning half of The New Science of Politics illustrates how a society's underlying concerns and interpretation of existence is formed. Second, the discussion of gnosticism points to a fundamental disjunction that occurs within modernity.

Voegelin concludes The New Science of Politics by pointing out that gnostic

the original term, such as apocalypticism, magic, and scientism (See: Eugene Webb, Eric Voegelin: Philosopher of History (Seattle and London: University of Washington Press, 1981), 200). Consequently, Voegelin's use of the term has been criticized with some scholars saying that the term confuses more than clarifies. Therefore, while some scholars are too brash in disregarding Voegelin's scholarship on gnosticism, Franz rightly said, “... there is a very real danger that less cautious polemicists will invoke Voegelin's categories without troubling themselves over the difficulties involved in establishing the presence of spiritual disease in the objects of their ridicule" (Eric Voegelin and the Politics of Spiritual Revolt, 14), this spiritual disease being the removal of transcendence from the society. 
corruption needs to be repressed and the forces of civilization restored. ${ }^{51}$ In modernity, gnosticism has contributed to the destruction of civilization and is spread by the general advance of modernity, through technology and globalization, and the radical corrosion of tradition.

At a point in The New Science of Politics Voegelin cites foreign policy as an example of how this radical corrosion of society exists within the modern world. $\mathrm{He}$ writes:

Our own foreign policy is a factor in aggravating international disorder through its sincere but naïve endeavour of curing the evils of the world by spreading representative institutions in the elemental sense to areas where the existential conditions for their functioning were not given. ${ }^{52}$

What Voegelin alludes to is the aggravation that arises from when a society's own interpretation of political order is replaced by an elite's form of thinking and acting, a perception which inform broader narratives.

This disjunction is increasingly strenuous because of the role that technology plays in global affairs. As technology develops, the planet becomes increasingly connected, bringing societies into closer contact with one another and creating the forums through which societies can contest the world. This process, which has come to be called "globalization", serves as the platform through which symbols confront one another. This clash of symbols is about who possess the best or most modern means of bringing order to the planet and whose truth "should rule the world". This

\footnotetext{
${ }^{51}$ Voegelin, Modernity Without Restraint, 241.

${ }^{52}$ Voegelin, Modernity Without Restraint, 128. In Chapter Two, this concept of gnostic foreign policies will be picked up with a discussion of Liberalism, a sort of foreign policy that seemingly claim elite knowledge and seeks to unhinge the symbolic structures illuminated by societies themselves.
} 
confrontation is about whether what Voegelin identifies as gnosticism can win, or whether societies who cling to a transcendent truth will react, resist, and be able to withstand the efforts made to overwrite their particular version of representation and truth. It is to this matter that we now turn. 


\title{
Section 2: Modernity, Globalization and Security
}

\author{
"Is the clash of empires the only test of truth, with the result \\ that the victorious power is right?" \\ - Voegelin, The New Science of Politics
}

As the previous chapter described, individuals illuminate meaning from within. This self-illumination happens on several levels, and, through this self-illumination, individuals and societies articulate their understanding of truth and interpretation of existence, through symbolic structures informed by their underlying concerns. This meaning is articulated in three representative forms- external, existential, and transcendental — all three which are necessary for a comprehensive understanding of a society's truth of existence and political order. Society can only succeed or progress if all three levels of representation exist harmoniously: if one is disrupted, society can fall into a spiritual crisis.

Yet, Voegelin argues that an individual societies' representation of truth is faced with a spiritual crisis in modernity, insofar as modernity has a disease. Voegelin identifies this disease as gnosticism, which, as analyzed in the previous chapter, seeks to de-divinize existence. Gnosticism, in Voegelin's view, has severed the connection between human beings and the spiritual, "the source of order in man and society," 53 by throwing human energies into progress, which is concerned with more temporal ways of living and which seeks to define human experience in solely temporal ways. Furthermore, gnosticism seeks to define human experience, and the truth of existence,

${ }^{53}$ Voegelin, Modernity Without Restraint, 131. 
in one particular way. As this one particular way is at odds with other societies, because their historical perspective and experiences are unique, it can run counter to the articulated understandings of societies. Consequently, gnosticism can act as the catalyst for the spiritual crisis of many societies. This catalyst is sped up in modernity, as the use and importance of technology and globalization has created an increasingly connected planet today. It is through these means that the gnostic nature of modernity arises: pitting symbolic systems against each other, dismantling tradition, and contributing to the radical corrosion of civilization.

Gnosticism, therefore, is an aggravating force. Gnosticism creates a disjunction between the symbols that are of the highest concern to a society (a societies' underlying concerns, which include the spiritual) and the overarching symbols that inform broader narratives (more temporal or modern ways of living). This disjunction between symbols is increasingly strenuous because of the project of modernity. In modernity, the planet becomes increasingly connected. Societies are brought in closer contact with one another and forums are created through which societies can contest the world. This process, which has come to be called "globalization", serves as the platform through which symbols confront one another. This clash of symbols becomes about who possesses the best or most modern means of bringing order to the planet and whose truth "should rule the world" whether gnosticism can win, or whether societies who cling to a transcendent truth will resist leaving their own understandings of existence behind. As we can see, it is the endeavour of modernity to organize action and thought according to the "best" and most modern principle. This endeavour would 
be impossible with technology.

In modernity, this struggle escalates, augmented by the increasing role of technology, and the reduction in the differences between the techne and the logos of different societies. ${ }^{54}$ Here, we speak of technology in the sense of it being a modern project, intent on developing the best 'modern science' for ordering the world. As Tom Darby explains, technology is:

[a] compound of the two Greek words techne and logos. Techne pertains to making and $\log o s$ to knowing, to practices and perceptions. But technology is not a compound in word only, for it is compounded from the copenetration of making and knowing. Technology is the progressively rational (efficient) arrangement of means and ends (for humans) and cause and effect (for nature). The former, therefore, has to do with practices and the latter with perceptions. Technology has as its project the transformation of both human and nonhuman. Efficiency, the goal of the projection of technology, is and can only be measured as the progressively diminishing difference between those means and ends or causes and effects. Thus, technology is (1) selfreferential, (2) relatively autonomous, (3) progressively sovereign, and, being so, (4) tends towards the systemization of nature both human and nonhuman. ${ }^{55}$

This, as Darby describes in a different article, "Overarching Metaphors and the Configuration of the Western City", is the modern project itself. ${ }^{56}$ Technology is the progressively rational, scientific, and efficient. It is the modern project of moving towards a system that is productive, specialized, systematic, teachable, and authoritative. And, as Darby says in "On Spiritual Crisis, Globalization, and Planetary

${ }^{54}$ Techne is the etymological origin of technology, defined as a particular knowledge that is productive, specialized, systematic, teachable and authoritative, and logos is a technical term for a principle in order and knowledge.

${ }^{55}$ Tom Darby, "On Spiritual Crisis, Globalization, and Planetary Rule" in Faith, Reason, and Political Life Today, ed. Peter Augustine Lawler and Dale McConkey (Maryland: Lexington Books, 2001), 52-53.

${ }^{56}$ Tom Darby, "Overarching Metaphors and the Configuration of the Western City," Design Principles and Practices: An International Journal 5.6 (2011): 218. 
Rule", it calls to mind visions of universal and homogenous rule or a "world state". 57

Consequently, in order to achieve this progressively more rational, scientific, and efficient system, modernity has a "gnostic-force" of its own. This gnostic force is the imposition of a certain symbolic structure, and the bringing in of an increasingly more modern and technological overarching metaphor.

To this end, this chapter will look at the disjunct between symbols of the modern world, informed by Liberal symbols derived from the Western world, and the symbols of other societies. I will begin by defining the concepts, drawing on Tom Darby's work, of underlying concerns and overarching metaphors. I distinguish the symbolic structures of Liberal states, states whose symbols have largely informed broader overarching narratives within the international system, with the symbolic structures created by the underlying concerns of other societies, societies who may actively resist these Liberal understandings of existence and political order.

Second, this chapter will look the project of modernity. The project of modernity is a consciousness that seeks to replace all spiritual truth with civil truth: ${ }^{58}$ to replace the symbols that concern an individual society with broader narrative seen to be universally applicable. Consequently, this chapter will look at the spread of these symbols, arguing that ordering international society according to the particular symbols of an overarching metaphor is seen as a way of mitigating conflict and creating security. The forced spread of Liberalism through globalization is done in an

\footnotetext{
${ }^{57}$ Darby refers to this result if "technology would become a totality (i.e. a total or complete system)" (53). In this case, this progressively technological system would be as best way to rule the planet and, as alluded to in the introduction, could possibly result in planetary rule. See: Darby, On Spiritual crisis.

${ }^{58}$ Voegelin, Modernity Without Restraint, 158.
} 
attempt to establish a Liberal peace on all borders as a way to avoid future insecurity. ${ }^{59}$ But, in doing so, the overarching metaphor begins to resemble the gnostic forces Voegelin identified in the latter half of The New Science of Politics. This will necessitate looking at the overarching metaphor as something that is perceived to be "evil" and disorientating, and which acts with an arrogance that arises from a believed mastery of reality and an unchallenged knowledge of the correct way of ordering existence. With these comments in mind, it is these competing symbolic structures and the use of these structures to create security that is the focus of this chapter.

\section{Symbolic Structures in Modernity}

In modernity, there are many types of symbolic structures in play. These symbolic structures are illuminated from within by the individuals who make up a society as a representation of their common understanding of their truth. Therefore, the articulation of this truth can differ substantially between societies, as different histories, relationships, and relations to the spiritual burden the individuals who comprise each society. As the mode and condition of existence differs between societies, the symbols of representation will differ as well.

Some societies, such as Western societies informed by Liberal metaphors, embrace symbolic structures informed by concerns such as individualism, constitutionalism, human rights, equality, the rule of law, democracy, free markets, and secularism. These symbols are specialized and are derived from traditions that are

\footnotetext{
${ }^{59}$ Mark Duffield, Global Governance And the New Wars: The Merging of Development and Security.
} London: Zed Books Ltd, 2001, 34. 
Western, and thus are profoundly different from non-Western traditions. Therefore, these symbols often do not resonate with other societies, such as, but not limited to, Islamic, Japanese, Buddhist or Orthodox societies. Rather, these societies may embrace different symbols that articulate their underlying concerns, representing the articulation of the existential and transcendental understandings that arise from their own lived histories and unique perspective. These symbols may include communitarianism, patriarchalism, arbitrary rights and law, autocracy, controlled markets, integration of religion within politics and, of particular interest to this thesis, intimate connections and relationships with the transcendent, to the extent that a society views itself as a representative of the beyond. It is not important what we name the symbol, only that we recognize that these symbols are illuminated from an inner realm of being. These symbols represent an intimate understanding of existence that is unique to a particular society. They symbols reflect what a society is intimately or highly concerned, and therefore, when faced with conflicting symbols which do not reflect their underlying concerns, a disjunction occurs. For the sake of this project, these symbolic structures will be separated into two types: underlying concerns and overarching metaphors.

\section{A. Underlying Concerns}

We have already discussed how a society illuminates its own articulation of truth. Voegelin's theory of truth and representation illustrates how a society's particular symbolic structure is formed. Elemental, existential, and transcendental symbols combine to articulate a symbolic structure that a society understands as 
representative of the truth of existence. This symbolic structure orders a society and constitutes a society's self-interpretation of itself as just. It is under this order that a society conducts its everyday activities within society and under which a society conduct itself on the international stage. This societal symbolic structure is comprised of the symbols that a society understands as needed for harmonious and ordered living.

Each of us can identify the symbols that are most important to us. These symbols are those that guide the narrative of our lives, and furthermore, are those that define us. These symbols are integral to our identities and to providing order within our lives. Furthermore, these symbols allow us to give our lives meaning. All societies operate in similar ways: the societal symbols, articulated from what means the most to the members of society, give societies action and purpose - order and meaning. These symbols, then, as they represent what is most important to a society are indicative of a societies' underlying concerns. Underlying concerns are the symbols that give meaning to an individual's existence, allowing him to focus on that which concerns him the most. An underlying concern is a society's particular understanding truth and particular relation to an inner realm, which culminates in the form of a political order particular to a society and is articulated in the form of elemental, existential, and transcendental symbols.

As an example, Voegelin speaks of the Russian constitution, which represents the idea, spirit and political culture, and thus is drawn from particular concerns found within the culture and community of a society. As another example, transcendental symbols indicate a society's intimate concern with the spiritual and the understanding a 
society has of itself as a representative of something beyond itself. These symbols are frequently associated with a society's understanding of the spiritual as instrumental to a society's order, and therefore illustrate the particular concern a society has with the transcendent qualities that guide its sense of meaning and purpose.

Different symbols are articulated by different societies because underlying concerns are particular to a society. Therefore, both the underlying concerns and societal symbolic structures are indicative of a specific identity held by a society. This articulation of truth culminates in the form of a political order particular to a society. It is a society's unique understanding of its own existence and of its belief as to what will create peace and what will provide a society with security.

These symbols can also be looked at as a social metaphor, an important method of cognitive thinking that plays a substantial role in the epistemological foundations of social systems. What is important about these underlying concerns or social metaphors is that they become the key to model building. Social metaphors become a mechanism for creating order, as this metaphor takes a collective which is orientated towards the same underlying concerns, and extracts symbols which serve to organize knowledge and create social structures and institutions which conserve, maintain, and legitimize certain patterns of relating and behaviour. This societal symbolic structure orders a society because it provides a society with a set of perceptions and practices that promote a certain cohesive behaviour.

These extracted symbols are seen as natural, in the way that theses symbols are illuminated from the inner realms of being: "connecting the soul, man, the city and the 
cosmos. ${ }^{60}$ The societal symbols encompass all three of Voegelin's forms of representation, and are indicative of a representative structure that is whole and harmonious, as each level is representative of something which a society is intimately concerned, which is born out of their being. As each level of representation is present, the symbolic structure represents a society's interpretation of its existence, creating "perceptions (thoughts) and practices (actions) [that] are themselves boundaries which constitute the limits and possibilities that give [societies] their unique spirit." ${ }^{\prime 61}$

These orders and interpretations of truth are seen in every society on the planet. These political orders can take many forms: as underlying concerns are not homogenous across borders, neither are the symbols extracted from them. Rather, these symbols are indicative of the self-illuminated interpretation of existence particular to a certain society, with a particular societal culture. As mentioned, these symbols are indicative of a unique spirit of a society, as they arise from a particular relation to an inner realm, particularly a unique relationship with the transcendent. Therefore, the order that materializes from symbolic systems can take many forms. As mentioned in the introduction to this section, these orders can be characterized by symbols such as individualism, constitutionalism, human rights, equality, the rule of law, democracy, free markets, or secularism, as is the case with most Liberal structures, and which have proved more palatable as broader narratives. Alternatively, orders can be characterized by symbols that could be seen as opposite or as polarizing symbols, representing the existential and transcendental symbols that arise from their

${ }^{60}$ Darby, Overarching Metaphors and the Configuration of the Western City, 216.

${ }^{61}$ Darby, Overarching Metaphors and the Configuration of the Western City, 212. 
own lived histories, as listed previously.

Regardless, these symbols arise from the particular interpretations of existence unique to a specific society or culture. These societal symbols constitute hard boundaries, particular ways of seeing and doing things, perceptions and practices, that are held by a group of like-minded individuals with similar lived histories, and thus similar understanding of existence and similar underlying concerns.

These symbols become embedded within its citizenry: they provide a tacit knowledge that underlies all beliefs. By extension, the activities of citizenry are guided by this knowledge. These symbols become a logos, which orders a society in a particular way, providing security through a common understanding and a plethora of social scripts on how to conduct activities and interactions. Consequently, these symbols, which are representative of underlying concerns, are important because it becomes a self-contained system that harbours the mainstream understanding of how society should operate.

In other words, the ruling social metaphor organizes society, legitimizing normative behaviours, dictating patterns of behaviours, and constructing acceptability. The social metaphor uses the self-illuminated underlying concerns to construct a shared perception of social reality. These symbols, therefore, act as an ordering mechanism for particular societies, introducing and legitimizing civic attitudes and behaviours. Order is created as individuals share a common understanding of how best to make a predictable system. 


\section{B. The Overarching Metaphor \& Liberalism}

An overarching metaphor, like the symbols of a society, is an interpretation of existence. It is a representative of a society's understanding of itself and of how best to order itself. Darby understands this as an overarching metaphor and defines it as follows:

an expression of the shared perceptions and practices of people living in a particular age. An age constitutes the boundaries of the perception and practices which define the limits and possibilities of events identifiable as an ensemble or pattern. ${ }^{62}$

An age is characterized by a particular techne, and thus a particular knowledge of what is the "best" way — and most specialized, systematic, teachable and authoritative - to conduct ones affairs. This particular knowledge is converted into the logos of the overarching metaphor, which seeks to establish order in a particular way.

In our particular age, the techne of this metaphor is one which declares "'artificial man' [as] superior to God's creation, nature." ${ }^{63}$ Darby calls this current metaphor the Post-Modern Age. This metaphor is indicative of globalization and is an attempt to create a global system of modern science or technology. Consequently, the perceptions and practices championed by the overarching metaphor are characterized by a particular knowledge that lacks the transcendental qualities of the societal symbolic structure previously defined, as it does not embody the particular spiritual underlying concerns of unique societies.

\footnotetext{
${ }^{62}$ Darby, Overarching Metaphors and the Configuration of the Western City, 215.

${ }^{63}$ Darby, Overarching Metaphors and the Configuration of the Western City, 219. This "artificial man" is indicative of a turn towards technology as the ordering element.
} 
In contrast, the modern overarching metaphor is characteristic of a symbolic structure that connects only man and the city. This symbolic structure fails to reproduce the transcendental because it is concerned with producing a product that is modern and technological. This is because the modern overarching metaphor is indicative of a new way of living, one that is characterized by symbols that are productive, specialized, systematic, teachable and authoritative. This is understood to be a system guided by technology, rather than by the cosmos or by a sense of the beyond. Therefore, the overarching systems, which create order, are indicative of a society severed from the transcendental, where "technology reveals itself as [the] risen Christ" ${ }^{\prime 64}$ and where the truth of a society is solely a body of propositions derived from world-immanent object.

Yet, overarching metaphors do not appear out of nowhere. Rather, they evolve through attempts by societies to globalize their underlying concerns. In this way, overarching metaphors are simply societal symbols amplified. Overarching metaphors begin as social metaphors but are able to transcend boundaries. The logos of overarching metaphors is applied on a level higher than an individual society. Overarching metaphors seek to transcend boundaries and unite civilization under a certain set of principles defined by a select elite, who are privy to the proper perceptions and practices that will peacefully order a society. Therefore, these overarching metaphors become a way for a society's understanding of its existence to be communicated — and furthermore adopted — to another society.

Overarching metaphors uproot the societal symbols of other societies. The

${ }^{64}$ Darby, Overarching Metaphors and the Configuration of the Western City, 221. 
symbols which had previously been adequate, as Darby says, "for sorting out the meaning of everyday life, allowing people to focus on that which concerned them the most — ... their Underlying Concern — had been violently uprooted" 65 by overarching metaphors, as they are communicated to other societies. The overarching metaphor becomes a mechanism for extending order. These symbols supersede a single individual society, finding its footing within the international structure and becoming a narrative for rule on a planetary scale. Therefore, overarching metaphors are indicative of broader narratives, ones that supersede the intimate and unique underlying concerns of individual societies.

This is primarily achieved through adoption of these overarching metaphors as normative behaviour on the international stage. Overarching metaphors, then, can be enshrined and championed in the work and methods of international institutions. These institutions are key to organizing behaviour on the world stage, promoting a set perceptions, and practices through international law, agreements, and norms. These institutions are informed by the symbols of a particular society, and thus legitimize a particular society's symbols as the proper perceptions and practices that will order the international community.

The products of these institutions become the overarching symbols of modernity. These overarching symbols become a model or a specific narrative through which a particular age, and particular societies, can understand their existence and organize on a planetary scale. The overarching symbols of our particular age- of modernity - are that of Liberalism, a symbolic structure born out of Western tradition

\footnotetext{
${ }^{65}$ Darby, Overarching Metaphors and the Configuration of the Western City, 216.
} 
and which thrives predominantly in Western societies.

The modern overarching metaphor is pervasive particularly because of the influence of technology. Technology allows for the possibility of developing a global system of modern science and technology. This makes a society's effort to globalize its particular symbols easier. While globalization is not a new phenomenon, it can, only in our age, be thought of on a planetary scale. Through the means of technology it is thereby possible for the overarching metaphor to have mechanism through which to infiltrate all corners of the world. Through technology it is possible to develop a universal and homogenous state that is ordered through the most efficient- by being scientific and rational — and therefore, the correct way of living.

In the Post-Modern Age, this is done through the pervasive symbolic structure of Liberalism. Through sources of global governance, such as Western international institutions, and the means of technology, societies who originally held these Liberal symbols as their personal societal symbolic structure have been able to globalize these symbols. Through actions such as agreements, norm development, et cetera, a Liberal symbolic structure has spread across international society. The truth of a Liberal order has become a mechanism through which the overarching metaphor engages, spreads, and eclipses the underlying concerns of the societal metaphor.

\section{Securing Society: The Security of a Universal Overarching Metaphor}

This modern overarching metaphor is efficient and rational, but is also seen as a means for security. The rationale behind globalizing these values is that it will bring 
order to the international community: with common symbols comes harmony, certainty, and security.

This concept of security saturates the language of modern politics. The rhetoric of security dominates the political vocabularies of our leaders and of institutions, and, to a considerable extent, our political imaginations are confined by the parameters of security. However, security is multifaceted. In its most easily identifiable form, security is a foundational requirement of the state in that it requires the state to seek its physical security, the protection of its territory and governance structures from others seek to cause material harm. But, more than this, security is about finding and establishing a stable place: security is about certitude. Security is about establishing a fixed set of principles and limits upon which society can stand, and which can guide society in its whole structure and essence. Security is about more than physical security; it is about ontological security and the ability to establish a self-evident condition for the existence of life. ${ }^{66}$

A society's concept of a secure planet will reflect the conditions that bring order to its own version of the truth of existence. The elemental, existential and transcendental symbol, which a society has articulated for itself, is the fixed point that is secure. Therefore, security becomes:

the predicate upon which the architectonic political discourse of modernity [is] constructed; upon which the vernacular architecture of modern political power, exemplified in the State, [is] based; and from which the institutions

\footnotetext{
${ }^{66}$ This discussion of ontological security will be picked up in Chapter Three. It builds upon the idea that political security draws from the ability to protect ones identity, and self-evident moral and social codes, and see this identity unchallenged; to see our identity as a point, like Leibniz wrote, on "which we can safely rest and from which we can set out without fear" (Philosophical Writings, 93.)
} 
and practices of modern (inter)national politics, including modern democratic politics, ultimately seek to derive their grounding and foundational legitimacy. ${ }^{67}$

When a society's underlying concerns are recognized as legitimate, security is gained through a binding back on the symbols that provide order for society. The modern project of security is characterized by a need to establish a certain set of symbols as the best possible and most efficient way of ordering any society. Modern international security involves an effort to consolidate the planet under one experience and, to an extent, involves the promotion of a society's own version of political reality in order to define security on its own terms.

To begin this analysis of securitization through a universal overarching metaphor, it is necessary to look at what constitutes this Liberal symbolic structure, the mechanism through which the overarching metaphor eclipses underlying concerns. The predominant symbolic structure in modernity is generally that which can be called Liberalism. This is the symbolic structure adopted by "Western" states and is composed of the symbols that these states see as natural and legitimate. Liberalism begun as the societal symbols of particular Western states, but with the advent of globalization, this structure has been promoted by the West to maintain and reinforce its status as global hegemon. Consequently, the symbols of Liberalism seek to become universal symbols. In order to understand what this universal symbolic structure is, it is important to unpack the meaning of "Liberalism", the overarching metaphor, and the West, the elite.

${ }^{67}$ Michael Dillon, Politics of Security: Towards A Political Philosophy of Continental Thought, New York: Routledge, 2003, 13. 


\section{A. Universal Liberalism}

Liberalism is not a singular theory. Yet, what tends to identify as Liberalism has several recognizable smybols such as scientific rationality, freedom, and the inevitability of technological progress. As Scott Burchill writes:

[Liberalism champions] limited government and scientific rationality believing individuals should be free from arbitrary state power, persecution and superstition. It has advocated political freedom, democracy and constitutionally guaranteed rights, and privileged the liberty of the individual and equality before the law. Liberalism has also argued for individual competition in civil society and claimed that market capitalism best promotes the welfare of all by most efficiently allocating scarce resources within society. ${ }^{68}$

Liberalism is an approach to order that emphasizes individual rights, constitutionalism, democracy, and limitations on the power held by the state. Furthermore, Liberalism tends to be skeptical, indifferent, or potentially hostile to the transcendent, seeking to free individuals from superstition.

Furthermore, Liberalism is also a distinctly Western symbol, amalgamating "Greek rationalism, Roman Stoicism, Christianity, Newtonian physics, and the critique of European ancient regimes. ${ }^{, 69}$ As its roots are in the West, Western states tend to see Liberalism as natural, legitimate, and as the truth of existence. Liberalism embodies the West's underlying concerns.

The West is made up of states that possess great power in the international system. It is a coalition of elite states politically structured as a complex network of

\footnotetext{
${ }^{68}$ Scott Burchill, "Liberalism" in Theories of International Relations, 3rd ed., ed. Scott Burchill et. al (New York: Palgrave MacMillan, 2005), 55.

${ }^{69}$ Donald J. Puchala, "World Hegemony and the United Nations," International Studies Review 7 (2004): 580.
} 
diplomatic power and policy coordination. Donald J. Puchala argues that the West's power can be defined in multiple facets: in political terms it is a club of democracies. In economic terms, a group of capitalist countries committed to free markets. And ideologically, it is the centre of Liberal internationalism. ${ }^{70}$ The West is a club dedicated to sharing and reinforcing its interest, aims and aspirations stemming from a set of similar symbols.

These interests, aims, and aspirations have been reinforced through a form of global governance concerned with establishing Western-Liberal power based "on the management and regulation of economic, political and social processes." ${ }^{, 71}$ Primarily, this management and regulation is done through the work of international institutions and agencies, which are the elements and instruments of these Liberal overarching symbols. These institutions and agencies articulate the overarching symbols in their processes, treaties, law, and norms, and enforce them as they institutionalize and regulate a world order characterized by Liberal internationalism. ${ }^{72}$

There exists a multitude of Western international institutions. They include, but are not limited to, the International Monetary Fund (IMF) and the World Bank (WB), the World Trade Organization (WTO), the United Nations, the European Union, and the North Atlantic Treaty Organization (NATO). These institutions embody the symbols that facilitate the expansion of the Liberal overarching symbols to other societies, yet are not the only bodies that facilitate the eclipse of other societies

\footnotetext{
${ }^{70}$ Puchala, 577.The modern "Western World" is understood from a culturally and sociological view to be composed of most States whose populations are derived from European cultures, including, the European Union, the Americas, South Africa, and Oceania. Liberalism has proven to be palatable in these regions.

${ }^{71}$ Duffield, 34.

72 Puchala, 571.
} 
underlying concerns. Other bodies help facilitate the spread of Liberalism, including Non-Governmental Organizations (NGOs), media, individuals, et cetera.

Yet, the United Nations, and its agencies, is one of the best illustrations of these symbols in action. From its beginnings, the United Nations can be understood as an instrument of United States foreign policy. The United Nations was largely an American creation and throughout the Cold War, the United States frequently used the United Nations as an instrument of United States foreign policy. Puchala cites numerous examples of United States influence, writing:

[The United States] goals were pursued in the United Nations via threatened vetoes in the Security Council, preponderant influence over the selection of successive Secretaries General, key positions and general overrepresentation in the Secretariat, and a deferential majority, consisting mostly of West Europeans and Latin Americans, in the General Assembly. ${ }^{73}$

Through these means, the United States was able to largely control the organization, using it as a means to shape and order the global community in its own vision. The same can largely be said today.

Yet, the United States is not the sole proponent of these Liberal symbols. The order created by these symbols is imposed and maintained by a "coalition of elites that collectively command sufficient power to direct world affairs in their interest." 74 These elites have a collective interest in reinforcing the overarching symbols, as they each see these symbols as articulating truth. As Puchala writes:

\footnotetext{
${ }^{73}$ Puchala, 573.

${ }^{74}$ Puchala, 576.
} 
The Western bloc projected substantially greater influence, most notably over the functioning of the world economy, but also in political affairs, and certainly over the activities and policies of international organizations. The Bretton Woods institutions are structurally controlled by the West; there is no mystery therefore about the Western bias conditioning their policies and programs. The United Nations similarly has been and continues to be a Western organization in the sense that the policies of the organization most often coincide with Western preferences. Those that do not coincide with Western preferences tend not to be financed and consequently do not get executed. $^{75}$

This coalition of elites continues to use the organization for its own purposes, which are not always aligned with the interests, concerns, and intentions of other societies. The purposes of universal Liberal symbols are that they are spread and reinforced in order to impose particular world order, a particular way of saying and doing things deemed correct by an elite. These institutions legitimate the norms of this order and absorb, and subsequently eliminate, other symbols that run counter to this order, swaying or compelling these societies to abandon their symbols for a "superior" order. $^{76}$

The symbols of Liberalism unite the West under a common a common expression of perceptions and practices. Their project is the universalization of Liberalism and they employ their power and dominance within the international discourse to impose their symbols upon others, displacing the symbols that concern others the most with these broader narratives of Liberalism. Through the influence of the West in these institutions, a set of universal symbols is promoted and reinforced, as Mark Duffield writes, through a:

\footnotetext{
${ }^{75}$ Puchala, 577.

${ }^{76}$ This description is reminiscent and owes much to the five universal norms of hegemony explained by Robert Cox in his 1983 article "Gramsci, Hegemony and International Relations: An Essay in Method."
} 
system of carrots and sticks where cooperation paves the way ... access to the wider networks of global governance, while non-cooperation risks varying degrees of conditionality and isolation. ${ }^{77}$

This is done not just for grandeur or control, but also for security, where hazardous, non-confirming societies with their own ways of saying and doing things are deemed "at risk" and thus isolated.

\section{B. A Secure System}

The project of modernity's result is a contest for the world: a contest for the right to provide the means of order the world, based upon who has the best or most modern means for bringing this order to the planet. Regardless of whether this contest takes the form of conquest through war, colonization, or dominance through international norms, as we see in this particular age, mankind has always been party to a contest concerning who has the best means or technology to order the planet.

Modernity's nature confronts these orders by presenting a set of Liberal symbols as the only way to order the world. These symbols are presented as the only order that will suitably bring peace to the world. Only a Liberal symbolic structure will provide security. As such, societies are expected to conform. These overarching symbols are key to joining the international societies "club". Adopting these symbols provides for a society access to certain privileges, relationships, and resources. Any society who resists this order is left out, perceived as a liability, and therefore ostracized from key parts of the international community. As the overarching symbols

\footnotetext{
${ }^{77}$ Duffield, 34 .
} 
are perceived the only legitimate order - the only legitimate truth and mode of representation that can enamour peace - those who resist are viewed as representing disorder and falsehood. Those societies are then targeted for change. The ultimate goal of the overarching symbols being to bring about a secure system.

Duffield analyzes this issue of using overarching symbols as a means of creating security in his book, Global Governance and the New Wars, where he examines the systems of global governance that have emerged in response to modern conflicts. Duffield analyzes the attempt by the international community to enforce certain normative structures and expectations - certain symbolic structures seeking to be universalized - as a way to "establish a Liberal peace on troubled borders." ${ }^{, 78} \mathrm{He}$ calls this new form of global governance "Liberal Peace", defining it as follows:

The idea of Liberal peace, for example, combines and conflates 'Liberal' (as in contemporary Liberal economic and political tenets) with 'peace' (the present policy predilection towards conflict resolution and societal reconstruction). It reflects the existing consensus that conflict in the South in best approaches through a number of connected, ameliorative, harmonizing and especially, transformational measures. While this can include the provision of immediate relief and rehabilitation assistance, Liberal peace embodies a new or political humanitarianism that lays emphasis on such things as conflict resolution and prevention, reconstructing social networks, strengthening civil and representative institutions, promoting the rule of law, and security sector reform in the context of functioning market economy. In many respects, while contested and far from assured, Liberal peace reflects a radical development agenda of social transformation. ${ }^{79}$

This Liberal peace is pursued in order to avoid what Duffield refers to as the "new" security concerns. He writes that the "new security concerns [are] not the threat of

\footnotetext{
${ }^{78}$ Duffield, 34.

${ }^{79}$ Duffield, 11.
} 
traditional interstate wars but the fear of underdevelopment as a source of conflict, criminalized activity and international instability." ${ }^{\prime 80}$ Broadly, this implies that there is a significant threat posed by societies that have underdeveloped systems of governance or political order. Underdeveloped, in this sense, identifies systems of governance which embrace a different interpretation of existence and order, and which differ from the system of Liberal governance.

Duffield points to two specific examples of these underdeveloped systems: Africa, in the sense that African societies possess vastly inadequate ordering systems, and Eastern Europe, in that these societies are reluctant to make the full transition to more adequate systems. ${ }^{81}$ These systems of governance and political orders are seen as a security threat because these systems embody a "political logic [that] can find violent and disruptive expressions." 82

While the ways in which other societies possess undeveloped symbolic structures is numerous, Duffield's book is narrow in focus, describing just one element of inadequate symbols, namely, economic underdevelopment. He focuses on how an undeveloped economic system is ostensibly indicative of instability. Duffield explores the literature which argues that the "causes of conflict [are located] in the modalities of underdevelopment and its associated pathologies of crime and terrorism." Underdevelopment is perceived as dangerous, because alternative symbols that inform principles and practices are incoherent and lead to a dysfunctional system of order.

\footnotetext{
${ }^{80}$ Duffield, 7.

${ }^{81}$ Duffield, 161. In these examples, the underlying concerns of the particular societies remain in tact, but are looked at by the Western world as underdeveloped and the primary cause of the security issues in these regions.

${ }^{82}$ Duffield, 14.

${ }^{83}$ Duffield, 114.
} 
Underdevelopment is indicative of a

social malaise resulting from a combination of various forms of scarcity (deep-seated poverty, environmental decline, uncontrolled population growth) with unrepresentative public institutions and weak civic culture (endemic social exclusion, widespread abuse of government office, economic mismanagement). ${ }^{84}$

All of these symbols ostensibly give way to conflict because these symbols create systems of government that are incapable of creating the circumstances to tend to individuals biological and psychological needs, as well as being indicative of circumstances where governments are unable to provide basic services. These symbols can lead to different forms of conflict such as the poor revolting against underdevelopment or an inadequate system of governance may attract criminally violent and vengeful leaders. ${ }^{85}$

This social malaise creates a context for conflict. The societal symbols in these societies run counter to stability. Therefore, these symbolic structures must be expunged, because, as Voegelin writes, "no public truth except the law of peace and concord" 86 can exist. To avoid this, Liberal symbols are advanced because they embody the only truth that can create peace and concord. Duffield argues that this is done through Liberal governance's participation in what he calls "developmentalism," 87 which structures itself around changeable and mouldable

\footnotetext{
${ }^{84}$ Duffield, 115.

${ }^{85}$ Duffield, 128.

${ }^{86}$ Voegelin, Modernity Without Restraint, 212. Recall that any "law of peace and concord" would, in Voegelin's view, and as described in Chapter One, is determined by an elite.

${ }^{87}$ This thesis focuses on "overarching symbols" as a large category of symbols associated with Liberalism. Yet, Duffield's understanding of developmentalism is much narrower, focusing on "changeable economic categories" (114). His book focuses on the creation of a narrative that seeks
} 
categories and the creation of a narrative that will encourage states to abandon their own symbols and adopt symbols associated with Liberalism, and, in turn, develop increasingly stable ways of conducting their affairs. In this way, "developmentalism, to an extent, is saying that only when societies attain certain [Liberal] economic, educational, and cultural standards is this trait [of conflict] tranquilized." Developmentalism seeks to extend a specific "structure of political reality;", a symbolic structure which the elite determines as the correct way of living, one which will provide a mastery of reality. Duffield's description of developmentalism, then, is reminiscent of the gnostic politics that Voegelin criticized in the latter half of The New Science of Politics.

Additionally, this social malaise exists regarding the transcendent. Particular societies are deemed more "at risk" because of their ties to something spiritual. These societies are seen as counterproductive to security because their political reality is structured by something seemingly irrational, unscientific and un-modern. This bridging of political and transcendent realities is seen as potentially dangerous and hostile. Consequently, there is an element to Liberal governance that seeks to apply developmentalism to the areas of transcendence, changing the structure of this spiritual reality, eliminating it in favour of something more dependable. Developmentalism, like gnosticism, seeks to de-divinize.

Duffield demonstrates that the international community, through a network of

to encourage states to abandon their own economic symbols and adopt Liberal economic symbols associated with free market capitalism. According to Duffield, this is done primarily through the commitment of donor governments and aid agencies, which help develop economies, while encouraging the development of certain structures that are more conducive to prosperity

${ }^{88}$ Duffield, 115.

${ }^{89}$ Voegelin, Modernity Without Restraint, 190. 
institutions, invests "in the business of transforming whole societies." ${ }^{.90}$ Inevitably, societies who cling to their unstable societal symbols and representations of the transcendent are exposed to resistance from enemies and targeted for entire social reconstruction. Liberal governance, then, concerns a radical reconstruction focused on eroding a society's individual interpretation of existence, or its societal symbols, and replacing its symbols with principles and practices that are scientific and rational, as opposed to "primordial, innate, and irrational cultural and ethnic [identities]."91 Duffield, then, echoes this idea discussed in the previous section of a more technological society: as transcendent is unpredictable and unknown, and therefore insecure, the focus of a Liberal symbolic structure of reality is on the immanent and the known.

This image is particularly striking when Duffield describes the difference between Liberal governance and other modes of representations, which embrace more holistic approaches, taking into account key characteristics such as selftransformation:

It can be summarized as the difference between seeing the world as a machine and seeing it as a living system or organism. The Newtonian view of the cosmos is that of a vast and perfect clockwork machine governed by exact mathematical laws. Within this giant cosmic machine everything can be determined and reduced to a scientific cause and effect. ${ }^{92}$

Thus, Liberal governance invokes a particular techne and logos, creating an international system of governance that is productive, specialized, systematic,

\footnotetext{
${ }^{90}$ Duffield, 58.

${ }^{91}$ Duffield, 110.

${ }^{92}$ Duffield, 10.
} 
teachable and authoritative- and secure.

While Duffield is primarily focusing on aid and humanitarianism as a way of promoting symbols of Liberalism and bringing international society under the symbolic structure of Liberal governance, his description of Liberal governance mirrors what was said earlier in this chapter, as Duffield describes an international system where a specific symbolic structure is advanced, seeing the symbolic structures and "will of [other] societies [as needing] to be put down." a wholesome effort, as all elements of a symbolic structure - elemental, existential, or transcendental - can potentially be a cause of insecurity. Now, conflict has the potential to arise from numerous facets:

The new conflicts are about identities and the status, culture and values of various groups. They are enacted in the social sphere rather than in areas familiar to traditional security policy. As a complement to the concepts that are the common currency of traditional power politics ('high politics'), such as security guarantees and arms control, we must now introduce concepts appropriate to the community level ('low politics'), which have to do with preventing crises, enhancing stability and reducing the element of unpredictability in the system. ${ }^{94}$

Consequently, the symbols that lead to this unpredictability need to be removed, replaced, or reconstructed lest these societal symbols become a handicap and threat to the international system. Not only are societal symbolic systems indicative of a false truth, they are also a detriment to global security. A shift in the symbolic structures of societies towards Liberalism is necessary as within alternative systems the conditions for instability and insecurity are prevalent, because the focus on the "cosmos" and

\footnotetext{
${ }^{93}$ Voegelin, Modernity Without Restraint, 210.

${ }^{94}$ Duffield, 36.
} 
improper, untruthful, symbols has the potential for violent outbreaks. Liberal overarching symbols solve this issue because these symbols establish a transfigured society whose allegiance to tradition is overcome by a new allegiance derived from truth. This Liberal truth will provide peace; thus, a society's underlying concerns must be uprooted and replaced with the concerns of a knowledgeable elite. ${ }^{95}$

\section{Security and Voegelin's Gnosticism}

Liberalism is a tool for security building. It seeks to usher in a new modern overarching metaphor as a means to globalize one set of symbols and concerns. One set of underlying concerns is seen as a means of security building because it serves to unite an international population, foster agreement, and facilitate harmony. Yet, this means of creating security relies on a knowledgeable elite to set restraints pertaining to the elements with which a society shall be concerned with. Thus, the security-building force of Liberalism is reminiscent of Voegelin's concept of gnosticism.

Recall that Voegelin defined gnosticism as a "purported direct, immediate apprehension or vision of truth without the need for critical reflection; the special gift of a spiritual and cognitive elite. ${ }^{.96} \mathrm{He}$ saw gnosticism as characteristic of two situations: transcendentalizing and immanentizing. Modernity's gnosticism takes the second form, "receding from transcendence." ${ }^{, 7}$ Thus, modern gnosticism attempts to create a world-immanent civilization, creating a political society ordered according to temporary truth, existing without the spiritual. The overarching metaphor seeks to do

\footnotetext{
${ }^{95}$ Voegelin, Modernity Without Restraint, 196; 210- 212.

${ }^{96}$ Voegelin, Autobiographical Reflections, 160.

${ }^{97}$ Voegelin, Modernity Without Restraint, 193.
} 
exactly this. Because Liberalism encourages skepticism of the transcendental, the overarching metaphor created order by drawing solely on the world-immanent. The symbols of the Liberal order, which inform the broader narratives spoken about above, act as the "civil theology of Western society." the world and create a political society receded from the spiritual. Liberalism is a process of de-divinization.

This is evident with modern Liberal symbols because global institutions seek to legitimize a certain set of perceptions and practices, specifying a certain type of behaviour. Liberal symbols expect societies in regions across the planet to adjust their global and individual historical perspectives to conform to more modern ways of living. These international institutions champion a certain set of perception and practices as necessary in order to gain acceptance. Whether a society accepts the overarching symbols as legitimate or not "establish[es] lines of inclusion and exclusion." ${ }^{99}$ If a society wishes to be included in the international community, and reap the benefits of Western institutions, it must accept the overarching symbols. A society must play the game and accept the role of technological progress.

The Western architects, the elite, of these international institutions push the advancement of society through existential methods. Liberalism in particular embodies these gnostic tendencies because it looks to technology and the scientifically rational to provide order, rather than the spiritual. Consequently, these overarching symbols are a phenomenon that uproots the very foundation and order of societies throughout

\footnotetext{
${ }^{98}$ Voegelin, Modernity Without Restraint, 233.

${ }^{99}$ Duffield, 34.
} 
the world in order by eliminating key parts of the human experience. These Liberal symbols enlighten the illiberal world with a set of symbols that are seen as the correct way to organize and rule the planet.

This demonstrates that the Liberal overarching symbols embody both of the two major intended effects of modern gnosticism identified by Voegelin. ${ }^{100}$ Firstly, Liberal overarching symbols create disorder in the world by compelling individual societies to abandon their underlying concerns and their own symbolic structures, and articulation of the truth of existence. But these symbols are seen as overcoming a disorder, as this vision of truth will transcend the world, creating order by universal acceptance. Secondly, Liberal overarching symbols look to technology to order the world, rather than to the cosmos as societies have done before. Thus, the intention of Liberalism is to sever the transcendent from political society to create order.

Like all gnostic revolutions before it, Liberal symbols champion an order that juxtaposes the self-interpretation encompassed in societal symbols, which articulate all areas of human experience (elemental, existential, and transcendental). Liberal symbols are a gnostic revolution as it descends to the level of existential representation, and while connected to the representation of truth, it ignores specific elements of history and experience. These overarching symbols are gnostic as these symbols, like Voegelin warns, have the tendency "not to supplement but to supplant the truth of the soul."101 The overarching symbols present one truth as capable of providing order. This constitutes an attempt to create a culture of "stability" by

\footnotetext{
${ }^{100}$ Voegelin, Modernity Without Restraint, 196; 243; 240-41.

${ }^{101}$ Voegelin, Modernity Without Restraint, 221.
} 
promoting a certain set of behaviours conducive to productive and peaceful interactions on the international stage, as discussed in the previous section of this chapter.

This gnostic movement seemingly has noble intentions. The elite see themselves as able to promote a symbolic structure that will provide the best means to order the world and thus are focused on imposing a specific understanding of truth in societies across the world. This gnostic formulation, like the ones before it, aims to order society according to a certain set of practices and principles, seen as a way to mitigate conflict and create security according to the terms it has deemed best.

Yet, like the gnostic revolutions which have come before it, which Voegelin describes, this gnostic formulation also has unintended consequences, because these Liberal symbols are "ambivalent to so-called traditional society.",102

Voegelin identified two important consequences of gnosticism, namely, alienation and repression. In regards to the spread of Liberal symbols by the elite in the international system, both of these consequences are apparent. Firstly, alienation is evident as the gnostic nature of overarching symbols attempts to orientate all societies towards one "truth", alienating individuals and societies in the process as their understanding of existence is interpreted for them, their underlying concerns are viewed as wrong and unnecessarily tied to something other-worldly. These societies are further alienated, as if they refuse to adjust to a Liberal order, they are excluded from international political society in the name of security. Secondly, these overarching symbols cause repression, as they require societies to sever a part of its ${ }^{102}$ Duffield, 123. 
self-interpretation, namely, the transcendent.

The international system employs international institutions to enforce the symbols of Liberalism as an international truth, and stifles the order of individual societies. Gnostic politics is, as Voegelin writes, "self-defeating in the sense that measures that are intended to establish peace increase the disturbances that will lead to war." ${ }^{\prime 103}$ These measures include the destruction of the truth of a society's soul and the insistence of gnostic politics to establish order counter to the principles of existence. The consequences of gnosticism are counterproductive to creating security, because these consequences create the conditions that spur individual societies' spiritual crisis. An effort to usher in a overarching metaphor that does not account for a individual society's unique underlying concerns will only result in similar consequences to that of gnosticism, namely, alienation and repression.

It is this naïve belief that only one set of symbols can correctly order the world, mitigate conflict, and create security, which spurs those societies' towards crisis. Prolonged exposure to alienation and repression may leave societies with only one option: resistance. It is this potential for resistance - this reaction in defence of a specific articulation of truth — that the following chapter analyzes.

\footnotetext{
${ }^{103}$ Voegelin, Modernity Without Restraint, 227.
} 


\title{
Section 3: Crisis and Resistance
}

\author{
"War is the only instrument left for adjusting \\ disturbances in the balance of existential forces." \\ - Voegelin, The New Science of Politics
}

Near the end of The New Science of Politics, Voegelin ponders how long the repression of societies' representations of truth will last. He writes:

... Other variants of Gnosticism, such as progressivism, positivism, scientism, are penetrating into other areas under the title of "Westernization" and development of backwards countries. ... In the face of this worldwide expansion it is necessary to state the obvious: that human nature does not change. The closure of the soul in modern Gnosticism can repress the truth of the soul, as well as the experiences that manifest themselves in philosophy in Christianity, but it cannot remove the soul and its transcendence from the structure of reality. Hence the question imposes itself: How long can such a repression last? And what will happen when prolonged and severe repression will lead to an explosion? It is legitimate to ask such questions when concerning dynamics of the future. ${ }^{104}$

Voegelin's question refers to the struggle societies encounter as societies attempt to retain their societal symbols as relevant and meaningful, as well as the action societies may take to react against prolonged exposure to symbols that are not their own. Recall that Voegelin asserts that societies are ordered by a specific symbolic structure informed by their unique environment. This ability to self-interpret is challenged in modernity. As the previous chapter discussed, overarching symbols like Liberalism are championed and imposed on all international society. This modern gnostic-like

\footnotetext{
${ }^{104}$ Voegelin, Modernity Without Restraint, 222. Here, Voegelin reflects upon the necessity to reflect upon these future dynamics of civilization. His remarks concerning human nature allude to his belief that the need for transcendence cannot be fully eliminated from society. Consequently, the movement towards the scientific, rational, and technological contains within itself a "self-defeating factor" as it produces something "like the counterprinciples to the principles of existence" (224).
} 
formulation pursues universal Liberal symbols, both because these symbols are understood as the only truth, but also because these symbols are used to securitize the international system. Peace and security are achieved at the expense of societal symbols: underlying concerns, which are critical to a society's identity, are eclipsed and eliminated.

Yet, as Voegelin argues, gnostic politics is self-defeating because it attempts to establish peace only increase the likelihood of disturbances that lead to war. ${ }^{105}$ This is because while some societies have accepted this new symbolic order as liberating, others see Liberal symbols as disorientating, harmful, and as a disruption to the balance of existential forces. While these universal Liberal symbols are intended to create security, enforcing these symbols run counter to the principles of existence, destroy the truth of the soul, and culminate in alienation and repression. Consequently, the exportation and enforcement of a universal Liberal symbolic structure, and consequently the ushering in of a new overarching metaphor, causes a spiritual crisis.

A spiritual crisis, as will be described below, arises when a society's underlying concerns, illuminated in the form of its societal symbols, are uprooted and become inefficient. As underlying concerns are tied to the transcendent, a change in symbols that persuades or forces a society to abandon its understanding of itself as a representative of the transcendent can cause a spiritual crisis because it provokes a major change to a society's self-interpreted understanding of existence. When a society's self-interpretation of existence is cast aside and existence is instead

${ }^{105}$ On this purpose of this war, Voegelin writes: "If a war has purpose at all, it is the restoration of the balance of forces" (Modernity Without Restraint, 228). 
interpreted for them, an identity crisis can arise because the symbols that used to provide order and meaning no longer do so. Consequently, a society's identity is in flux. This change causes a spiritual crisis.

All political action is self-referential. We see this with the articulation of levels of representation, as described by Voegelin, and we also see it with the formation of potential resistance movements, the form that the explosion against the overarching metaphor may take. Resistance is self-referential as it arises from a need to defend a society's identity, underlying concerns, and interpretation of existence. Societies, as well as individuals, may see resistance as an instrument through which they can oppose unwelcome symbols and changes to their political order. Consequently, these agents undertake resistance, and, furthermore, potentially means of conflict, as a way to defend their self-interpretation of the meaning of existence and as way to protect their identities.

The spread of the Liberal symbols can lead to an increasingly less secure international community as societies attempt to restore what they interpret as a balanced order. The spread of overarching symbols is a phenomenon that uproots the very foundation and order of societies throughout the world. This Liberal symbolic structure has eroded the spiritual capacity of societies, giving rise to despair and conflict. Faced with this challenge, Voegelin's question is warranted: at some point societies will rise against the forces that seek to expunge their understanding of existence. The focus of the following chapter will be to look at the consequence of this disjunction between symbols, the spiritual crisis, and the insecurity that this crisis 
causes. Furthermore, this chapter will look at the rise of resistance identities, as societies seek to defend their understanding of existence. It is to this matter- this modern security crisis - to which the rest of this study dedicates itself.

\section{Identity and Spiritual Crisis}

Individuals and societies interpret existence for themselves. As demonstrated in Aristotle's Ethics and Politics, societies prescribe themselves meaning, rather than wait for others to interpret meaning for them. This meaning is articulated through symbols, which serve as the ordering mechanism of societies and creates the structure of political reality on which these societies can rest and feel secure. These symbols, which make up a societies interpretation of existence, are meaningful to these societies and therefore arise out from the things that are the most important to a society: a society's underlying concerns.

When these underlying concerns are challenged by competing concerns, specifically ones that hold considerably more clout in the international system, such as the symbolic order of Liberalism, a society's symbolic structure can be uprooted and become inefficient. When this happens, a spiritual crisis is suffered by the society itself.

A spiritual crisis is a form of identity crisis. ${ }^{106}$ It is a crisis of the spirit resulting

${ }^{106}$ While the term "spiritual crisis" is used consistently in this thesis, this phenomenon may also be called an "existential crisis". In either sense, it refers to a moment where an individual questions or is unable to handle his experiences and is unable to prescribe meaning or value to his life. Voegelin, in the Eclipse of Reality, uses the term "pneumapathology" to describe a "disease of the spirit". This term referred to a disorientated consciousness where there is a tension between divine transcendence and earthly realities, as divine transcendence was once the source of meaning, but the loss of transcendent faith in modernity causes a crisis. Voegelin argued that a consequence of this disease was a withdrawal by those connected with the transcendent from worldly demands, a concept that 
in the loss of an individual and collective sense of purpose and meaning. A spiritual crisis is brought on by a fundamental and drastic disruption to the meaning systems that inform a societies' understanding of existence. It is a crisis spurred by a disjunct between the symbols which concern an individual society the most and the overarching metaphor. In this crisis, these symbols are rendered meaningless: the unique external, existential, and transcendent representations of truth are stripped away from their informants. Consequently, those undergoing such a spiritual crisis are unable to make sense of their experiences, both personal and collective.

Being unable to make sense of experience occurs when drastic changes or disruptions occur regarding a society's truth, order, and structure of meaning. As there is a distinct spiritual component to a society's interpretation of existence, a spiritual crisis can be brought on when society faces a new order that seeks to eliminate that spiritual capacity, creating tension between divine and worldly realities.

This immanentizing nature of modernity is found in Liberal symbols that our modern world has embraced. These symbols are focused on ordering a society based on symbols that are world-immanent, rather than allowing societies to look to the cosmos, or any form of the spiritual, for political order. Liberal symbols are concerned with the rational and scientific- with the technological. This is a stark contrast to the articulation and representation identified by Voegelin, when he argues that beyond external and existential representation existed transcendental representation. These transcendental symbols are an articulation of a society's understanding of itself as 
something connected to the spiritual. These transcendent symbols are understood as truth and, in Voegelin's view, this form of representation is equally important and needs to be articulated in order for harmonious balance to exist.

Thus, the immanentizing nature of modernity can cause the spiritual crisis as it contributes to the destruction of the truth of the soul. It does this, first, by eliminating the spiritual's role in structuring political order and, second, by championing symbols that run counter to the principles of existence, as understood by societies. A society's truth, and underlying concerns, which provide society with meaning and reason to act in a particular way, is stripped away. This sudden uncertainty regarding experience brings forth the spiritual crisis.

Spiritual crisis is not a new concept. Darby argues that there have been four such spiritual crises in the history of the West: the Classical Pagan Age, the Classical Christian Age, the Modern-Technological Age, and, now, the Post-Modern Age. ${ }^{107}$ In each of these ages, a new overarching metaphor is introduced to society and, in the process, disrupts and replaces the previous one. An overarching metaphor is defined by Darby as "an expression of the shared perceptions and practices of a people living in a particular Age."108 Overarching metaphors are created from symbols that reflect a particular vision. Thus, when each of these ages arises, it introduces a new way of seeing and way of doing things, and a new way of interpreting existence. In the process, previous ways of seeing and doing things are deemed inefficient and

${ }^{107}$ It is important to recognize that that these ages and new overarching metaphors do not arise randomly, but evolve naturally in time and history. Therefore, while potentially disorientating, these new metaphors are not unnatural and the progression towards planetary rule is in fact logical. See: Darby, On Spiritual crisis, and Darby, Overarching Metaphors and the Configuration of the Western City, 215-221.

${ }^{108}$ Darby, Overarching Metaphors and the Configuration of the Western City, 215. 
meaningless.

The first overarching metaphor of the West tied the meaning of existence directly to the pagan gods. This metaphor consisted of explanations that were mythical and magical forms of causality. Purpose and meaning were given by cosmological and spiritual authorities, which meant that the gods were at the centre of all explanations and causes. Transcendental representation was articulated and incredibly important to the truth of existence, as this age understood itself as representative of the pagan gods - something beyond or transcendent to itself. These mythic-magic forms of causality were understood as truth, as the pagan gods provided a political society with meaning and reason to act in a particular way. Society was ordered in a particular way, as it was representative of this transcendental authority.

This mythic-magic metaphor was disrupted by the onset of a new age, that of the Classical Pagan Age. This age consisted of a metaphor illuminated by Plato and Aristotle's "'natural' [or cosmological] metaphor which connects the natural Overarching Metaphor to the experiential ground of raw experience (=Underlying concern) and allow for it to be shaped into meaning expressed as temporal discourse." 109 The age is representative of meaning as related to nature, both nonhuman as well as the nature of man. This overarching metaphor arose to take the place of the "dead gods of Greece.",110

When the Peloponnesian War broke out, the Athenian cosmopolitan empire continued to expand and the authority of Classical Pagan Philosophy eclipsed the

\footnotetext{
${ }^{109}$ Darby, Overarching Metaphors and the Configuration of the Western City, 215.

${ }^{110}$ Darby, Overarching Metaphors and the Configuration of the Western City, 216.
} 
pagan pantheon, the previous overarching metaphor. Thus, a new overarching metaphor created a new vision: a cosmological or natural metaphor that rooted itself in a renewed existential ground, where causality was attributed to patterned changes in the heavens or the cosmos. And, with the introduction of the Classical Pagan Age and its new overarching metaphor, the first spiritual crisis set in. The new overarching metaphor rendered the mythic-magic metaphor inefficient and meaningless. Thus, the new overarching metaphor left those who identified with the previous metaphor to attempt to make sense of their confused and now meaningless identities. Astronomy became the new truth, and version of transcendental representation, replacing the mythic-magic metaphor, the previous articulation of truth.

To summarize, "the metaphor that had been previously been adequate for sorting out the meaning of everyday life, allowing people to focus on that which concerned them most — ... their Underlying Concern - had become violently uprooted." 111 Consequently, the individuals and societies who clung to their previous patterns of perceptions and practices, and the previous age's way of interpreting existence and truth, were faced with disorientation, loss of purpose and meaning. These societies faced a profound challenge to their identities. They faced a spiritual crisis.

The Post-Modern Age, the current spiritual crisis facing societies, is indicative of globalization and attempt to create a global system of modern science or technology. As explored in the second chapter, globalization - the actualization of technology - is an attempt to consolidate the world under a system of principles and

${ }^{111}$ Darby, Overarching Metaphors and the Configuration of the Western City, 216. 
practices that are scientific and rational; to envelop international society "within a giant cosmic machine [where] everything can be determined and reduced to a scientific cause and effect." ${ }^{112}$ Transcendental representation, or an articulation of a society's ties to something beyond, is effectively removed, as spirituality does not serve this scientific and rational order. The Post-Modern Age, then, attempts to create a universal and homogenous international society by instilling the same knowledge throughout the world's entirety. Truth, and understanding of existence, would be the same across borders: societies would confirm to the most correct, efficient, and secure way of living embodied within Liberalism.

This age, and spiritual crisis, continues today with the spread and enforcement of Liberal symbols. These symbols, as Duffield highlighted, through their influence in international institutions serve as a method through which to impose a particular world vision, and subsequently, order. Liberal symbols appear to be intent on uniting the international community under one set of overarching symbols, symbols that are the basis for the overarching metaphor. The Post-Modern Age, then, focuses on the establishment of a universal and homogenous planetary society by expecting societies to abandon symbols which are not embedded in the overarching symbolic structuresymbols which are not thought to be the best way to order international society and to bring about security, as discussed in the previous chapter. This conflict of two competing symbolic structures, and the elimination of one, causes those who cling to other symbolic structures to face a spiritual crisis. As far as the international community is concerned, other symbolic structures are no longer suitable for this new

${ }^{112}$ Duffield, 10. 
age, for a universal and homogenous planetary civilization. The elite who dictate and reinforce these overarching symbols see this universal civilization are only successful if order is established on the elite's terms. And, ostensibly, there is only a particular set of symbols can bring about order.

Thus, a spiritual crisis is a crisis of identity and of purpose. It results in a disorientation or uncertainty of how to order oneself and occurs when the ways in which man makes sense of his experience no longer work for him. This renders his experience meaningless.

In modernity, with the rise of Liberal symbols, a disjunct occurs between the symbols that are of the highest concern to an individual society - a society's underlying, and frequently spiritual, concerns - and the overarching Liberal symbols which inform broader narratives. Thus, the naiveté that only one set of symbols can correctly order the world, mitigate conflict, and create security spurs a spiritual crisis because a society's truth is rendered meaningless. As well, society is no longer connected to the existential and transcendental truths in which society had grounded its experience, understanding, and order. This represents a considerable challenge to the identity and political reality of a society, and of individuals, as a society's ability to self-interpret its own existence is criticized.

This challenge to the identity of individuals and societies causes a "sense of binding together by binding back to an original idea or revelation." ${ }^{113}$ Voegelin points

\footnotetext{
${ }^{113}$ Barry Cooper, New Political Religions, or An Analysis of Modern Terrorism (Missouri: University of Missouri Press, 2004), 7. Here, Cooper builds upon Roger Scruton's study of terrorism in The West and the Rest: Globalization and Terrorist Threat, arguing that all understandings of terrorism must begin from an understanding of religiosity or spirituality that is central to the activities of societies.
} 
to this in The New Science of Politics, arguing that prolonged and severe repression of the soul will lead to a backlash, as while Western societies have seemingly embraced a Liberal symbolic structure and political order without transcendence, the same cannot be said for other societies, such as Chinese, Hindu, Islamic, and primitive civilizations.

Voegelin argues that an explosion of resistance will take place, as the transcendent experience of man cannot be silenced easily. Individuals of society whose symbolic structures are challenged will bind together to react and resist these changes to their symbolic structure and will form trenches of resistances. These trenches of resistance, like all political action, are justified by symbolic narratives, which are connected to a larger order of meaning, and are created to protect this larger understanding of truth and of existence.

Thus, the spread of Liberal symbols and a new overarching metaphor creates the necessary political and philosophical conditions for resistance identities. This is because while modernity aims to recede from the importance of the soul, this closure can only "repress the truth of the soul ... it cannot remove the soul and its transcendence from the structure of reality."114 While modern symbolic orders will aim to repress the transcendent from being represented in the order of society, transcendence will not go away easily. It is to the forms of resistance that answer this repression that our focus turns.

Scruton's book attempts to characterize the essence of the Western Civilization as distinct from others, essentially arguing that nation-states established in the West are built upon secular law. The "rest" does not hold the same characteristics and when threatened by the characteristics of the West, these societies bind back on this religiosity or spirituality central to their activities. For further information see: Roger Scruton, The West and the Rest: Globalization and Terrorist Threat, Delaware: ISI Books, 2002.

${ }^{114}$ Voegelin, Modernity Without Restraint, 222. 


\section{Manifestation of Spiritual Crisis: Ontological Security and Resistance}

As chapter two established, the attempt to unify the international system under one symbolic order - a Liberal symbolic order - is an attempt to create security. The advent of the new overarching metaphor, ushered in by Liberal symbols championed by Western states and institutions which promote a particular vision, is indicative of an attempt to establish a harmonious international society that confirms to this most correct, efficient, and secure way of living: a unified and homogenous Liberal planetary order. Yet, as chapter two also revealed, not all societies view a new overarching metaphor as liberating. Rather, some societies feel that this uprooting of their underlying concerns, by displacing and replacing their societal symbols, is violent and disorientating.

The West's globalization of their symbolic structure is met with a degree of acceptance, but Liberalism also faces hesitation and confusion because the overarching metaphor, like Voegelin's gnosticism, has two main consequences for societies: alienation and repression. This uprooting - this severing of a societies interpretation of existence - results in a spiritual crisis.

A spiritual crisis not only renders a society unable to make sense of their experience, but can also render them hostile to the influence of outsiders. Not all societies will readily accept this symbolic order, but furthermore they might actively resist it. The violent uprooting of a society's underlying concerns will prove to be unreasonable and impossible to accept, and consequently, as Voegelin notes in The 
New Science of Politics, a society will fight back. ${ }^{115}$ A spiritual crisis, then, because it is afflicted with feelings of alienation and repression, can create the necessary political and philosophical conditions for resistance identities, and for conflict.

Primarily, this is because a spiritual crisis can be indicative of an ontological insecurity problem within society. An important premise of international relations security theory is that states seek to ensure their physical security, the protection of a states' sovereignty, territory, and autonomy. But, as Anthony Giddens, Jennifer Mitzen, and others have asserted, this view of security is limited. States also seek to ensure their ontological security.

Ontological security is derived from a sense of stability and continuity regarding the events of a society or individual's experiences. Mitzen defines ontological security as "security not of the body but of the self, the subjective sense of who one is, which enables and motivates action and choice." ${ }^{\prime 16}$ Ontological security requires that an individual be able to apply meaning to his own life - as we are not a tabula rasa, but rather active participants in the self-interpretation of our own existence - and provide himself with a sense of order, derived from that which he sees as important. Ontological security is the security response that looks to account for a society's certitude.

\section{A. Ontological Security}

To understand the relevance of underlying concerns in international relations, it

\footnotetext{
${ }^{115}$ Voegelin, Modernity Without Restraint, 222.

116 Jennifer Mitzen, "Ontological Security in World Politics: State Identity and the Security Dilemma" European Journal of International Relations 12 (2006): 344. This draws on the definition of security offered in Chapter Two, continuing the discussion begun there.
} 
is necessary to draw on Anthony Giddens' notion of ontological security, and of individual self-identity being used to understand societal behaviour. Self-identity is defined as "the self as reflexively understood by an individual in terms of his or her own biography." 117 This self-identity is routinely created and sustained through the agency of the individual for the purpose of determining action and purpose in the existential uncertainty that is human existence.

Ontological security is also a society's ability to be known in specific ways by others. Recalling the imagery reiterated at the beginning of this chapter, societies and individuals self-interpret, determining the symbols that allow them to make sense of existence, and to dictate purpose and meaning, themselves. It is integral that the individuals within society determine this self-identity themselves. Furthermore, in order to preserve ontological security, it is integral that this self-interpretation is relatively stable, meaning that there needs to be a sense of personal and societal continuity. If not, an individual's capacity for agency is nullified or, at least, severely underwritten. ${ }^{118}$

The purpose of ontological security is to ensure an individual's - and by

${ }^{117}$ Anthony Giddens, Modernity and Self-Identity: Self and Society in the Late Modern Age (Cambridge: Polity Press, 1991), 52. This concept of ontological security is formalized by Giddens, but is seemingly borrowed from the works of Erikson, and the term itself coined by the psychologist. R.D. Laing. In The Constitution of Society, drawing on Erikson, Giddens uses this term to identify something that has become "an inner certainty as well as an outer predictability" (53). Giddens notion of individual self-identity as security is drawn on in many studies seeking to understand state behaviour. According to Giddens, in his sociological analysis of modernity, individuals create a "self" for the purpose of negotiating existential and cognitive uncertainty. Mitzen expanded upon Gidden's theory by applying it directly to state action.

${ }^{118}$ Voegelin, in his comments at the conference to celebrate the $20^{\text {th }}$ anniversary of his Walgren Lectures, commented on one of the primary tasks of philosophy in the present age in that it is to "reestablish the meaning of reason and to reestablish the philosophical consciousness of existence in the "In Between" of reality" (McKnight, 123), particularly as the meaning of reason has been redefined in ways that deform the nature of human experience. That is to say, philosophy can be charged with aiding in the protection of ontological security. 
extension a society's - agency. Ontological security is security of "the self, the subjective sense of who one is, which enables and motivations action and choice."119 It requires that societies be able to determine who they are themselves: their sense of self and of who they are cannot be prescribed for them. Jennifer Mitzen argues that societies need for ontological security is similar to the need for physical security:

... the need for ontological security is extrapolated from the individual level. Ontological security refers to the need to experience oneself as a while, continuous person in time - as being rather than constantly changing — to realize a sense of agency. Individuals need to feel secure in who they are, as identities or selves. Some, deep forms of uncertainty threaten this identity security. The reason is that agency requires a stable cognitive environment. Where an actor has no idea what to expect, she cannot systematically relate ends to means, and it becomes unclear how to pursue her ends. Since ends are constitutive of identity, in turn, deep uncertainty renders the actors identity insecure. ${ }^{120}$

Consequently, if the goal is complete security, ontological security cannot be marginalized. Therefore, the political scientist, to use Voegelin's imagery, cannot walk in and start determining a society's symbols and interpretation of existence for a society without disrupting this stable cognitive environment. This would create deep uncertainty and disorientation.

Mitzen argues that when something threatens or is not consistent with an individual's interpretation of meaning, this impacts the individual's ontological security. Deep uncertainty is a threat to identity. Mitzen argues "ontological insecurity refers to the deep incapacitating state of not knowing which dangers to confront and

${ }^{119}$ Mitzen, 344

${ }^{120}$ Mitzen, 342.Mitzen further argues that in order to pursue ends that are in line with one's identity, individuals are motivated to create cognitive and behavioral certainty by establishing routines. This is similar to the perceptions and practices which Duffield discussed, in that these routines allow an individual to continually pursue and complete actions that reflect his underlying concerns. 
which to ignore, i.e. how to get by in the world." ${ }^{121}$ In the case of ontological insecurity, an individual is unable to make sense of how to order and conduct himself in the world. He cannot "relate ends systematically to means in the present, much less plan ahead. In short, [he] cannot realize a sense of agency." ${ }^{122}$ This contrasts substantially with an ontological secure person, where an individual can make sense of his experiences and see the logic to his actions and the means-ends relationships that govern his life.

Mitzen also extended Gidden's concept of ontological security from individuals to societies. She argues that societies feel deep uncertainty and disorientation exactly as individuals do, because society is the collective identity of individuals. In this way, deep uncertainty and disorientation are created in societies by Liberal symbols. Introducing Liberal symbols into societies whose interpretation of existence and meaning differs fundamentally from these new intrusive symbols challenges the identity of these societies. The new Post-Modern Age, and its overarching metaphor discussed in the section above, creates deep uncertainty and disorientation, as it is not consistent with a societies' personal interpretation of existence. It creates ontological insecurity.

Ontological insecurity is experienced by a society as a result of the structural change and cognitive challenge posed by globalization and the spread of Liberal symbols. The spiritual crisis experienced by a society because its own symbols for making sense of the world are dismantled and deemed meaningless. Mitzen argues that

\footnotetext{
${ }^{121}$ Mitzen, 345.

${ }^{122}$ Mitzen, 345.
} 
actors become attached to practices that endow them with agency and let them feel authentic. ${ }^{123}$ These practices are the societal symbols - all three levels of elemental, existential and transcendental symbols - that allow a society to interpret existence, and conduct and order itself. Recognizing these symbols as what regularizes and drives the social environment minimizes uncertainty and allows a society to impose order.

Yet, it is a misconception to understand societal symbols as ordered because they are indicative of a "perfect" society. Rather, societal symbols provide order because they represent the existence and truth of society as it is true to the selfillumination of the individual. Order is derived from the inner realm of individuals: it is ordered because it is the articulated truth of existence of individuals - and of society. It is ordered — and furthermore secure — as individuals are granted the agency to define their own circumstances. A political reality informed by societal symbols is ordered as it allows a society's underlying concerns to be the driving force of their social environment and, thus, provides individuals with ways of knowing the world, of knowing how to act, and instils in individuals a sense of certainty that they have some sort of knowledge of how or why the world functions as it does.

Regardless, identities can change - this is necessary for both individual and collective growth, as well as for cooperation. And, as the description of past spiritual crises demonstrated, it is possible for a new overarching metaphor to be introduced and to be internalized. It is also possible for identities to originate in dominant institutions, like argued in the previous chapter with the influence and presence of

${ }^{123}$ Mitzen, 347. 
international institutions such as the United Nations. But these symbols only become a society's identity when they are accepted, internalized, and when societies construct meaning around these symbols, accepting them as truth. ${ }^{124}$

Yet, because societal symbols, including symbols of the transcendent kind, sustain a society's identity and allow society to preserve their underlying concerns, societies become attached to them. Letting go of these symbols, or internalizing those that originate outside of their own society, amounts to sacrificing that sense of identity. Consequently, it is hard to do.

\section{B. Resistance Identities and Insecurity}

Giddens' and Mitzen's discussion of uncertainty is reminiscent of the consequences Voegelin identifies as appearing because of gnostic politics. While the overarching metaphor should not be seen exactly as gnosticism, because it is a particular vision that is brought on by changes in the order of history, overarching metaphors do have consequences similar to the gnostic politics Voegelin described. For instance, uncertainty is an emotion brought on by alienation and repression. Consequently, Voegelin's predictions on the reaction to gnosticism, in that societies will rise up and resist, identifies the reaction that a society may have in response to losing their sense of ontological security. Alienation, repression, and uncertainty all lead to a common reaction, namely, resistance.

Resistance can become a way of preserving — or at least fighting to restoreontological security. The act of resistance can lead to conflict. But, as Mitzen tells us,

${ }^{124}$ Manuel Castells, The Power of Identity: The Information Age - Economy, Society and Culture Volume II. (Oxford: Blackwell, 2010), 7. 
societies may prefer conflict to the "unsettling conditions of deep uncertainty as to the other's and one's own identity." "25 Resistance, in Voegelin words, can be "the only instrument left [for societies] for adjusting disturbances in the balance of existential forces."126 Thus, when faced with a spiritual crisis, where a society's underlying concerns are forcibly replaced, resistance becomes a way of attempting to retain a society's underlying concerns — of reinstating its claim on its ontological securityand is seemingly a society's only recourse.

Voegelin claims these forces that seek to replace a society's underlying concerns, and in modernity, increasingly its transcendental symbols, would be met with hostility. Societies would inevitably rise up against this subversion of their personal understanding of truth. The reality of Voegelin's claim can be seen in the formation of resistance identities, an appearance that can be seen in the actions of societies in different areas of international society.

Resistance identities are promoted by groups who feel marginalized and devalued or who feel that they could once make sense of the word but are now losing ground. These identities form in response to a spiritual crisis, and seek to reassert the importance of underlying concerns and societal symbols. Manuel Castells, in The Power of Identity, defined a resistance identity as follows:

[resistance identities are] generated by actors who are in positions/conditions devalued and/or stigmatized by the logic of domination, thus building trenches of resistance and survival on the basis of principles different or opposed to those permeating the institutions of

\footnotetext{
${ }^{125}$ Mitzen, 342.

${ }^{126}$ Voegelin, Modernity Without Restraint, 228.
} 
society. ${ }^{127}$

In his description, Castells points to the idea that these resistance identities are particularly appealing to those marginalized by globalization and those who have experienced a radical reconstruction of their social or spiritual conditions and of their political reality.

The conditions of modernity force a particular identity on societies. As discussed before, Liberal symbols encourage and enforce a specific set of perceptions and practices in the international system, which consequently force societies to assume particular identities. This is a substantial ontological security issue and is a recipe for violence. Resistance identities are a way of attempting to preserve a society's underlying concerns and trying to rally these identities against the Liberal cause. It is a fight for recognition:

It constructs forms of collective resistance against otherwise unbearable oppression, usually on the basis of identities that were, apparently, clearly defined by history, geography, or biology, making it easier to essentialize the boundaries of resistance. ... Religious fundamentalism, territorial communities, nationalist self-affirmation, or even the pride of self-denigration, inverting the terms of oppressive discourse, ... are all expressions of what [Castells] name[s] the exclusion of excluders by the excluded. That is building of a defensive identity in terms of dominant institutions/ideologies, reversing the value judgement while reinforcing the boundary. ${ }^{128}$

Holders of this identity may build trenches of resistance and construct forms of collective resistance against new, unwanted, Liberal symbols. When societies endure a

${ }^{127}$ Castells, 8. Here, Castells builds off of a definition offered by Craig Calhoun, where Calhoun explained the emergence of identity politics. See: Craig Calhoun, Social Theory and the Politics of Identity. Cambridge: Blackwell Publishers Inc., 1994.

${ }^{128}$ Castells, 9. 
spiritual crisis, this resistance identity is likely to arise as an attempt to combat the overarching metaphor that attempts to expunge its identity, truth, and symbolic structure. These resistance identities are groups or societies who actively act out against infiltration or corruption of their individual truths and symbolic structures by the elites' overarching metaphor.

As Duffield alluded to, Liberal governance is about radical reconstruction focused on eroding a society's unique interpretation of existence. This form of security building is concerned with replacing a society's symbols, and its underlying concerns, with principles and practices that are scientific and rational. Consequently, international society attempts to construct a universal and homogenous society "out of isolated individuals who are not orientated toward a common purpose but are motivated by their individual passions." ${ }^{, 129}$ Resistance movements arise to defend the underlying concerns that inform a society's own purpose- their own passions. Modern conflict and security issues arise not from a scarcity of resources or traditional interstate wars but from a need to defend societal symbols, and in many cases, a connection with the transcendent or a societies' spirituality: a "semi-Western or semi Modern new culture looks like an assault upon tattered tradition." ${ }^{130}$ It is the radical corrosion and reconstruction of society that stimulates conflict and causes insecurity.

These trenches of resistance are built as a direct reaction against the new Liberal symbols and overarching metaphor. These identities bind back on the underlying concerns originally held by the society, and build trenches of resistance

\footnotetext{
${ }^{129}$ Voegelin, Modernity Without Restraint, 235.

${ }^{130}$ Cooper, 18.
} 
that are instrumental and purposive. The encroaching overarching metaphor is seen as a clash of empires: proponents of this version of truth of existence are seen as the enemy. Consequently, resistance identities expand in response to Liberal foulness. Societies use resistance as a way to defend its own representation of truth, its ability to define itself, and society's right to have a sense of stability and continuity regarding the events of an individual's experiences, and to assert its ability to be known in a specific way by others.

In short, resistance identities are undertaken by societies who are struggling to retain or maintain their ontological security. The development of a resistance identity is a form of "binding together by binding back to an original idea or revelation," "131 or binding back to a society's underlying concerns. Resistance identities seek to preserve these underlying concerns, in response to a modern system and modern metaphor, an unwelcome addition.

Primarily, this binding back focuses on an element of truth and representation — an element of identity — that has been lost in modernity. Societies binds back on the transcendent, an element of truth that is key to understanding existence, as developed in chapter one. This loss of the transcendent indicates a loss of political reality, as a societies interpretation of existence is ultimately severed. It indicates a sense of uncertainty and a loss of self-knowledge.

Resistance is about "homecoming" or a sense of coming back to those symbols that make society and individuals feel safe and secure. Homecoming pertains to our identity and being able to experience ourselves as a continuous person in time by ${ }^{131}$ Cooper, 7. 
having knowledge both of where we came from, where we are going, and our purposes and motivations for getting there. Resistance identities can be formed as a society attempts this homecoming, as a society actively tries to retain the role of the transcendent within its identity. Attaining "homecoming" requires that a society be able to live according to its underlying concerns, including viewing itself as a representative of the beyond.

These resistance identities which emerge from a spiritual crisis can manifest in different ways, varying from groups who retreat from broader national societies or from international society, groups who actively defy international principles and norms, exhibit blatant indifference to norms, issue military action, or in some cases, commit to actions that come to be known as "terrorism".

In some forms, the security threat to international society can be minimal, as a society's resistance identity manifests in the form of a commune, which attempts to remove itself from international society. An example of this minimal disruption to international security is cited by Castells in his exploration of civil resistance and its methods. Castell's draws on the example of Mexico's Zapatista Army of National Liberation (henceforth Zapatista) as a resistance identity which has rebelled against the oppression of the new global order, specifically the symbols enforced in Zapatista society by the North America Free Trade Agreement (NAFTA). ${ }^{132}$ The Zapatista's

\footnotetext{
${ }^{132}$ Castells offers a detailed analysis of the Zapatistas in The Power of Identity (75-86) that calls the Zapatista movement one that opposed "social solidarity to organized crime from the power of money and government" (manifesto of Movimiento Civil Zapatista, August 1995). While the full extent of the Zapatista movement will not be explored here, it is important to note that Castells highlights the impact of Liberalization policies on the economy and lifestyles of the communities of Chiapas and Oaxaca. For example, Castells states: "the final blow to the fragile economy of peasant communities came when Mexican Liberalization policies in the 1990s, in preparation for NAFTA,
} 
intentions are not to engage militarily but rather to engage in a strategy of civil resistance, using the Internet to diffuse information and raise the issues of social exclusion, political corruption, and of the significant consequences the new global order - the Post-Modern Age - has on small Mexican communities and their way of living, on their political autonomy and their identities. As part of their resistance, the Zapatistas have effectively removed themselves from Mexican society, creating their own province, and adopting strategies to attempt to establish political autonomy.

In this example, it is clear that the Zapatistas have "bound back" on specific values and symbols with which they are most concerned. Primarily, this has focused on traditional Mayan beliefs and practices, with a focus on anti-globalization. The focus of the Zapatistas on their traditional Mayan beliefs as a key part of their underlying concerns has driven them to focus their goals and policies on a relationship between mankind and the environment. For this reason, one of the main tenets of the Zapatista's anti-globalization agenda has been control over their own resources, reflecting their belief of a sort of marriage between mankind and the earth. ${ }^{133}$

While the Zapatista's were prepared to die — and some did — to preserve their underlying concerns, and thus their identity, the resistance movement has, for the most

ended restrictions on imports of corn, and eliminated protection on the price of coffee. The local economy, based on forestry, cattle, coffee, and corn, was dismantled. Furthermore, the status of communal land became uncertain after Salina's reform of the historic article 27 of the Mexican Constitution, which ended communal possession of agricultural property by the villagers, in favour of full commercialization of individual property, another measure directly related to Mexico's alignment with privatization in accordance with NAFTA” (78). Consequently, it is possible to see that the symbols of Liberalism, when enforced upon Mexican communities, whose order constituted (and consists, as their resistance continutes) of different ways of living, causes resistance, as seen in the rise of the Zapatistas' against the reincarnation of oppression in the form of the new global order: NAFTA, and Liberal symbols.

${ }^{133}$ Castells, 75-81. 
part, abstained from military action and violent forms of activism. Yet, this is not the case with many resistance identities. Contemporary violence has roots in this "West versus the rest" mentality, where societies are forced to assume a particular identity, as it causes societies to feel marginalized, anxious and uncertain. Consequently, the disjunct between underlying concerns and the overarching symbols encapsulated by international society can be a recipe for substantial instability in the international system as societies exercise violent means of protecting their identities and of assuring their ontological security.

In The New Science of Politics, Voegelin argues that when there is complete "unrecognition of reality" 134 societies can undertake actions, which, while morally insane in the "real world", are viewed as a viable action as societies attempt to reorientate reality to a version that they recognize. These actions are more contentious forms of resistance, and include violent methods, such as war and terrorism.

When societies are unable to recognize reality, a society's resistance identity can adopt "second reality" to deal with the consequences of a spiritual crisis and the common experience of the new overarching metaphor. This second reality exists as an effort to preserve a society's underlying concerns and is constructed to reflect a version of reality that a society's recognizes and where a society's feels secure.

This concept of the second reality is the focus of Voegelin's essay The Eclipse of Reality, where he describes the phenomenon of a second reality, a term Voegelin used to refer to a political action where an individual arbitrarily denies existence of an aspect of the world. Voegelin writes:

${ }^{134}$ Voegelin, Modernity Without Restraint, 226. 
[An individual] will rather put his imagination to further work and surround the imaginary self with an imaginary reality apt to confirm the self in its pretense of reality; he will create a Second Reality, as the phenomenon is called, in order to screen the First Reality of common experience from his view. ${ }^{135}$

In this case, as demonstrated in the previous chapters, the first reality is that of the Post-Modern Age and the symbols of Liberalism, brought on by technology and the international system. But, this is a reality that society cannot recognize as it does not reflect a society's understanding of political reality, as none of society's underlying concerns inform this reality. A second reality is different, as it is an imaginary reality driven by a desire to maintain a connection to the beyond and to a society's previous experiences, rather than adapt to the new experiences in facing society. Thus, a second reality is an imagined reality that ignores new experiences in favour of binding back on old, stable, and familiar experiences.

A second reality, then, is not the reality of common experience. A second reality does not adapt to the changing symbols of the world and it does not progress to embrace the new overarching metaphors, however logically progressive. Thus, in cases where a society rejects the Liberal symbols, it may create a second, imaginary, reality that does not acknowledge the common experience of a new overarching metaphor. This second reality does not view the symbols of Liberalism as integral symbols to international society.

Barry Cooper, in his book New Political Religions, or An Analysis of Modern

${ }^{135}$ Eric Voegelin, "Eclipse of Reality," in What is History? and Other Late Unpublished Writings, ed. Thomas A. Hollweck and Paul Caringella. Vol. 28 of The Collected Works of Eric Voegelin. 1990. (Columbia: University of Missouri Press, 1999), 112. 
Terrorism, draws a connection between Voegelin's understanding of second realities and modern terrorism. Here, terrorism is described as being a bolder form of resistance and the culprit of much insecurity in modern international society. Cooper clarifies the elements of the second reality by pointing to three qualities. He explains: 1) There is a discrepancy between the imaginary reality and the reality of common experience; 2) the international act of projecting an imagined reality at variance with the reality of common experience; and 3) the specific, concrete individual who has deformed his human being into something else and has permitted this deformed, imaginary self to eclipse his human being. Second realities are, in Cooper's words, created when individuals or societies "[are] wracked with guilt at the misery of his fellow human beings and is deeply angered at the appearance of evil in his society." ${ }^{, 136}$

As Voegelin wrote in The New Science of Politics, any symbolic structure that does not resemble a society's interpretation of existence is viewed as an evil and as an intruder in a society's reality. Cooper maintains this position, arguing that the depth of frustration which stimulates a resistance identity, and furthermore a second reality, motivates society and animates terrorism. Cooper writes that "revolutionaries are unable to endure themselves in the real world, therefore they create an imagined reality." ${ }^{137}$ Therefore, a second reality is constructed for two reasons: it arises as a way to allow a society to remain immersed in their own truth of existence, and it can justify ostensibly altruistic and sacrificial actions intended to create a desired reality, where a society's own underlying concerns are accepted as truth.

\footnotetext{
${ }^{136}$ Cooper, 48.

${ }^{137}$ Cooper, 47.
} 
To this end, a second reality brings a society into "general conflict between the world of his imagination and the real world." ${ }^{\prime 38}$ This mode of consciousness has major security consequences for international society. A second reality brings society into conflict with the broader metaphor of international society and of modern living, encouraging actors within society to actively and aggressively resist influence from enemies. Thus, the potential consequence of the second reality is that it justifies the "application of violence to human material in order to create a desired product." 139

Within this imagined reality, Cooper argues that individuals are able to remove hesitation to commit otherwise inherently illegitimate acts for instrumental purposes, specifically, the willingness to kill innocents. Consequently, as Voegelin writes, "the conflict within reality turns out to be a disturbance within reality." 140 These acts represent a willingness to sacrifice not only an individual's self to attain his "desired product" - a reality that embodies society's underlying concerns - but to also sacrifice others to achieve a desired political reality. Thus, as usually morally insane acts are now justifiable acts, the possibility for violence increases. A society's inability to recognize and deal with political reality results in tension, war, and an

${ }^{138}$ Voegelin, "Eclipse of Reality", 112. Voegelin calls the self who experiences this conflict a shrunken or contracted self. This self is faced with the question of "what is reality?" and, consequently, the necessity of making a choice that will determine the self's being by making a choice between an imagined reality (the reality the self chooses and which reflects the self's most intimate concerns) and the reality of common experience (the overarching metaphor of the time).

${ }^{139}$ Cooper, 39.

${ }^{140}$ Voegelin, "Eclipse of Reality", 112. This point elaborates on Voegelin's understanding of a spiritual crisis (or disease) and the tension experienced by individuals confronted with a world order and symbolic system they view as disturbing and disorientating. Cooper builds off Voegelin's thought by arguing that when dealing with this disturbance, they exhibit a willingness to undertake drastic actions to correct this disturbance and re-orientate reality in line with a society's underlying concerns. This disturbance is corrected through a second or imagined reality, which could also be viewed as a form of gnosis itself, as individuals or society's project this reality as a way to counter a disturbance and to embrace certain knowledge as it were the actual world. 
increasingly insecure international political environment.

Transcendence plays an essential role in this disturbance, as society's ability to recognize itself as a representation of something beyond is crucial to recognizing and coping with political reality. Consequently, a society attempts to reassert the transcendental symbols key to its interpretation of existence. As modernity is characterized by an attempt to firmly plant the world's symbolic order in the worldimmanent, removing the ability of a society to see itself as representative of a cosmic or transcendental order. As chapter one discussed, transcendental symbols are key to self-illumination. The meaning of existence - truth — for many societies is grounded in the divine. The ability to experience oneself as a continuous being in time necessitates the need to understand ones experience as representative of something behind. As a result, this link to the transcendence is a vital to the desired product, which a society wishes to actualize in the reality of common experience.

For some societies, order is understood as orientated toward the will of a God or towards the cosmos. ${ }^{141}$ Liberalism, in contrast, replaces existence under God with symbols that have nothing to do with this mode of existence. Rather than being orientated toward the will of the transcendental, in modernity, and under Liberalism, societies see existence as orientated toward the scientifically rational and worldimmanent. This illustrates a clash between orders that are divinely willed and humanely realized. As Voegelin tells us, a public order that seeks to eliminate the transcendent persuades societies to close off from the spiritual and to become entirely world-immanent is repressive and antagonistic. This has a profound effect on human

${ }^{141}$ Cooper, 84. 
self-understanding as uncertainty is created concerning motivations and purpose. Consequently, those societies who see their link with the transcendent being severed or deemed meaningless develop a second reality because it is the only way to cope with the loss of these transcendental symbols and the sense of being representative of the beyond.

Individuals and societies are unable to endure themselves within a reality that fails to account for the link to the transcendent. This reality runs counter to the symbols that a society sees as the truth of existence, and furthermore their ontological security. This disjunction causes a spiritual crisis, which a society reacts to by creating a second reality, which seeks to protect a society, allowing society to retain a connection to past experiences. Therefore, for many, this second reality is founded on the crisis between faith and reason, with many societies, as Cooper writes, seeking "to actualize a second reality derived from the Bible, the Koran, or The Turner Diaries" "142 or a variety of complex religious symbols that numerous societies see as fundamental to the truth of existence. Through this second reality, individuals exhibit a willingness to sacrifice themselves and others to achieved a "desired product": a society that is orientated towards the will of the transcendent. This ontological necessity to have a connection with the transcendent serves to legitimize even the most violent of acts, because the need to recognize oneself, one's understanding of truth, and one's political reality is so strong.

Cooper argues that Islamic terrorism, or militant political (jihadist) Islam, is one expression of a violent reaction to a spiritual crisis, where some members have

\footnotetext{
${ }^{142}$ Cooper, 48.
} 
adopted a second reality as a means of coping. According to Cooper, this is a society where there is no choice between God and Caesar. As Cooper explains, Islam combines temporal and spiritual activity into a single act. Even the most trivial and ordinary actions are seen as a profound act of faith. ${ }^{143}$ Modern metaphors such as Liberalism, then, pose a genuine threat to this order because the international community has perceived Islamic societies' purposes and practices to be inefficient and counter to security building. This is because profound acts of faith are seen as irrational and inefficient. To resist this, some jihadist societies have developed a second reality where undertaking inherently illegitimate acts for the sake of reestablishing a symbolic order with links to the transcendent is justified. For these societies, their purpose is to actualize a desired reality, overthrow the new overarching metaphor and the symbols of Liberalism, and reassert the divinely willed understanding of existence.

In this example, the link to the transcendent is key to the creation of this resistance identity. Whereas societies who embrace the overarching metaphor are skeptical of transcendence and concentrate on the world-immanent, societies, such as ones who take up militant political Islam, see the transcendent as instrumental in every action, however trivial and ordinary. It is the transcendent that gives them purpose. Thus, when facing the possibility of being stripped of this ability to act as a representative of the transcendent, these societies act defensively, using their belief in the transcendent and a second reality as a justification for resistance. This resistance includes using violent methods and illegitimate acts, which in turn brings societies into

${ }^{143}$ Cooper, $78-79$. 
conflict with one another, and consequently leaving populations vulnerable, by waging wars or issuing acts of "terrorism". The actions undertaken by these societies are ostensibly altruistic and viewed by the society as a form of martyrdom because the overarching metaphor is an illegitimate political reality that must be corrected and replaced with a political reality that accounts for the transcendent. Violent actions are necessary and war is the only option left to rebalance political reality and to reestablish the correct truth of existence.

Therefore, it is possible to see that the actions undertaken by these resistance identities that embrace a second reality pose a genuine and violent security threat to the international community. The struggle of societies to retain their underlying concerns provides societies with the reasons needed to embrace violent methods to defend their underlying concerns. Thus, the securitization of society using Liberal symbols only furthers the "us versus them" mentality and encourages the contest for the planet. Security is not created, but rather fought for because societies attempt to achieve their own security, including ontological security, at the expense of others.

In conclusion, similar to the goal of Liberal overarching metaphors, the goal of resistance identities is security. In both cases, societies crave certainty. For resistance identities, this certainty can only be achieved through the reestablishment of their individual interpretation of existence as truth. This, then, is the goal of all resistance identities and of all those who embrace a second reality. The goal of this resistance, even the more violent ones, is not to die, but rather to overcome the spiritual crisis by overthrowing the symbols that cause uncertainty. Consequently, the spread of 
overarching symbols for the sake of security seemingly only begets insecurity, eroding the spiritual capacity of societies, giving rise to despair, conflict, and insecurity. 


\section{Conclusion}

“... politics, thus, is self-defeating, in so far as its disregard for the structure of reality leads to continuous warfare."

- Voegelin, The New Science of Politics

The purpose of this thesis is to posit that there are identifiable philosophical conditions that lead to conflict and insecurity in the international system. In particular, modernity is characterized by a turn towards an overarching metaphor, which embraces the scientifically rational and the world-immanent, and, in the process, eclipses the underlying concerns of individual societies. This includes a radical reconstruction of these societies' symbolic structures, including the tendency to expunge a society's belief that they are representatives of something transcendent to themselves. From here this thesis concluded that the conditions of the overarching metaphor do not guarantee security and, more importantly, can actually foster the conditions for insecurity, despite the attempt by the international community to use the particular and unified vision of the overarching metaphor to securitize.

To reach this conclusion, I began with Voegelin and his theory of truth and representation. I established that Voegelin's understanding of how a society articulates its particular understanding of the truth of existence is key to recognizing how individual societies understand political reality, and what each society views as secure. Furthermore, using Voegelin's The New Science of Politics, I posited that a society self-interprets its existence for itself, constructing a symbolic structure that articulates its underlying concerns, a set of stable symbols with which society is intimately 
concerned and which inform a society's identity, and thus allows society to feel safe and secure.

Second, chapter two established that these underlying concerns find themselves at odds with the symbols which characterize modernity, specifically with Liberalism, the particular vision with which the overarching metaphor is brought in. These Liberal symbols are used as an attempt to securitize the international community by enforcing one unified, homogenous vision and world system, but in the process, causes a spiritual crisis within societies who do not recognize or confirm to this interpretation of truth.

The ensuing spiritual crisis may then give rise to resistance identities that seek to resist the particular vision of the overarching metaphor. As a way of resistance, these identities bind back on their underlying concerns as a way to protect their ontological security. Through this binding back, societies reject, and can actively oppose, the world-immanent nature of Liberal symbols, which focus on the scientific and rational, and ignore the transcendent. Resistance identities form in order to uphold their underlying concerns, and illustrate an open and potentially violent defiance of other symbolic structures. Or, in modernity, resistance identities defy the Liberal order, an order that is intended to promote stability and peace, to manage and regulate the processes of international discourse, and specifically to regulate states deemed at risk. Therefore, although Western-Liberal states view other symbolic structures as the primary cause of insecurity, the forced adoption of Liberal overarching symbols may actually cause a disjunction between underlying concerns and overarching metaphors. 
And thus the overarching metaphor creates further insecurity.

The actions undertaken by societies, specifically when immersed within a second reality, as chapter three discussed, poses a genuine threat to international society. This is because a second reality provides societies with the reasons needed to adopt resistance identities and to imagine realities that allow them to embrace violent methods to protect their underlying concerns. These violent methods, no matter the form, destabilize the international community because these methods bring societies into direct conflict with one another, leave populations vulnerable, and risk actions labeled as "terrorism", which only bring about fear.

By way of conclusion, it must be recognized that neither reality nor philosophy can be reduced to a one universal system. As societies have different views of the structure of reality, plurality must be respected. This means that for security to be a viable option, the transcendent must be seen as vital to truth and representation. As some societies understand their political orders foremost as representative of something transcendental - and because this can be a primary motivation for contemporary acts of terrorism - it must be understood that peace can only be achieved when the transcendental is reintroduced to modern living.

Finally, it is possible to see that resistance identities can destabilize the international community. Resistance identities provide a counter argument to the common discourse that there is one correct way to order the planet. Consequently, these acts of resistance can create a management crisis in the world. In structural terms, resistance identities destabilize international political society because they serve 
as examples of our more complex, plural, and interdependent world, but also of a world where globalization allows these complexities and different symbolic structures to interact. Resistance identities challenge the idea of centralized power and that the elite have special knowledge concerning what is secure. Insecurity is created because the question of order - the question of who should rule the world and how - is unclear and because there exists uncertainty over how to exist in the modern world.

Certainty, which humans crave, and consequently peace and security, can only be achieved when societies can understand themselves as continuous beings in time: when a society's ontological security is intact. This requires the ability to articulate all three levels of representation, including a society's transcendental symbols, and for a society to articulate its own understanding of existence, order, and political reality. 


\section{Bibliography}

Burchill, Scott. "Liberalism" in Theories of International Relations, 3rd ed., edited by Scott Burchill, Andrew Linklater, Richard Devetak, Jack Donnelly, Matthew Paterson, Christian Reus-Smit and Jacqui True. New York: Palgrave Macmillan, 2005. 55-83.

Calhoun, Craig. Social Theory and the Politics of Identity. Cambridge: Blackwell Publishers Inc., 1994.

Castells, Manuel. The Power of Identity: The Information Age - Economy, Society and Culture Volume II. Oxford: Blackwell, 2010.

Cooper, Barry. New Political Religions, or An Analysis of Modern Terrorism. Missouri: $\quad$ University of Missouri Press, 2004.

Cox, Robert. "Gramsci, Hegemony and International Relations: An Essay in Method" in Gramsci, Historical Materialism and International Relations, edited by Stephen Gill. Cambridge: Cambridge University Press, 1993. 49-66.

Darby, Tom. "On Spiritual Crisis, Globalization, and Planetary Rule" in Faith, Reason, and Political Life Today, edited by Peter Augustine Lawler and Dale McConkey. Maryland: Lexington Books, 2001. 35-60.

--------. "Overarching Metaphors and the Configuration of the Western City." Design Principles and Practices: An International Journal 5.6 (2011): 211-233.

Dillon, Michael. Politics of Security: Towards A Political Philosophy of Continental Thought. New York: Routledge, 2003.

Duffield, Mark. Global Governance And the New Wars: The Merging of Development and Security. London: Zed Books Ltd, 2001.

Franz, Michael. Eric Voegelin and the Politics of Spiritual Revolt: The Roots of Modern Ideology. Baton Rouge: Louisiana State University Press, 1992.

Giddens, Anthony. Modernity and Self-Identity: Self and Society in the Late Modern Age Cambridge: Polity Press, 1991.

---------. The Constitution of Society: Outline of the Theory of Structuration. Berkeley and Los Angeles: University of California Press, 1984. 
Huntington, Samuel P., "The Clash of Civilizations?” Foreign Affairs (1993): 22-49.

Leibniz, W. Philosophical Writings, edited by G.H.R. Parkinson. London: Everyman, 1973.

McKnight, Stephen A. "Gnosticism and Modernity: Voegelin's Reconsiderations Twenty Years After The New Science of Politics," Political Science Reviewer Vol. 34 (2005): 122.

. The Modern Age and the Recovery of Ancient Wisdom: A Reconsideration of Historical Consciousness, 1450-1650. Columbia: University of Missouri Press, 1991.

Mitzen, Jennifer. "Ontological Security in World Politics: State Identity and the Security Dilemma" European Journal of International Relations 12 (2006): 341370 .

Plato. The Republic of Plato. Translated by Allan Bloom. New York: Basic Books, 1991.

Puchala, Donald J. "World Hegemony and the United Nations." International Studies Review 7 (2004): 571-584.

Scruton, Roger. The West and the Rest: Globalization and Terrorist Threat. Delaware: ISI Books, 2002.

Voegelin, Eric. Autobiographical Reflections. Edited by Ellis Sandoz. Vol. 34 of The Collected Works of Eric Voegelin. Columbia: University of Missouri Press, 2006.

------. "The Eclipse of Reality." In What Is History? and Other Late Unpublished Writings, edited by Thomas A. Hollweck and Paul Caringella. Vol. 28 of The Collected Works of Eric Voegelin. Columbia: University of Missouri Press, 1999.

-------. Modernity Without Restraint: The Political Religions; The New Science of Politics; and Science, Politics and Gnosticism. Edited by Manfred Henningsen. Vol. 5 of The Collected Works of Eric Voegelin. Columia: University of Missouri Press, 2000.

Webb, Eugene. Eric Voegelin: Philosopher of History. Seattle and London: University of Washington Press, 1981. 